\title{
Application of the Mineralogy and Mineral Chemistry of Carbonates as a Genetic Tool in the Hydrothermal Environment
}

\author{
Javier Carrillo-Rosúa ${ }^{1,2, * \mathbb{D}}$, Salvador Morales-Ruano ${ }^{2,3}$, Stephen Roberts ${ }^{4}\left(\mathbb{D}\right.$, Diego Morata ${ }^{5}(\mathbb{D}$ \\ and Mauricio Belmar ${ }^{6}$
}

1 Departamento de Didáctica de las Ciencias Experimentales, Universidad de Granada, Campus Universitario de Cartuja, 18071 Granada, Spain

2 Instituto Andaluz de Ciencias de la Tierra, Universidad de Granada-C.S.I.C., Avd. Las Palmeras 4, 18100 Armilla, Spain; smorales@ugr.es

3 Departamento de Mineralogía y Petrología, Universidad de Granada, Avd. Fuentenueva s/n, 18002 Granada, Spain

4 National Oceanographic Centre, School of Ocean and Earth Science, University of Southampton, European Way, Southampton SO14 3ZH, UK; steve.roberts@noc.soton.ac.uk

5 Department of Geology and Andean Geothermal Center of Excellence (CEGA), Facultad de Ciencias Físicas y Matemáticas, Universidad de Chile, Plaza Ercilla 803, Santiago 8370450, Chile; dmorata@ing.uchile.cl

6 Centro de Mineralogía Avanzada/SGS Minerals S.A., Puerto Madero 130, Parque Industrial Puerto Santiago, Pudahuel 9020000, Chile; mauricio.belmar@sgs.com

* Correspondence: fjcarril@ugr.es

check for updates

Citation: Carrillo-Rosúa, J.; Morales-Ruano, S.; Roberts, S.;

Morata, D.; Belmar, M. Application of the Mineralogy and Mineral

Chemistry of Carbonates as a Genetic Tool in the Hydrothermal

Environment. Minerals 2021, 11, 822.

https://doi.org/10.3390/min11080822

Academic Editor:

Panagiotis Voudouris

Received: 16 June 2021

Accepted: 26 July 2021

Published: 29 July 2021

Publisher's Note: MDPI stays neutral with regard to jurisdictional claims in published maps and institutional affiliations.

Copyright: (c) 2021 by the authors. Licensee MDPI, Basel, Switzerland. This article is an open access article distributed under the terms and conditions of the Creative Commons Attribution (CC BY) license (https:// creativecommons.org/licenses/by/ $4.0 /)$.

\begin{abstract}
The mineralogy and mineral chemistry of carbonates from various hydrothermal deposits, including volcanic-hosted Au-Cu epithermal, "Chilean Manto-type" $\mathrm{Cu}(-\mathrm{Ag})$, stratabound Mn, and Ag-Ba vein deposits from Spain and Chile, were investigated. Dolomite-ankerite ( \pm siderite) was found in variable amounts within the epithermal deposits and associated hydrothermal alteration, whereas calcite was found either within barren veins or disseminated within the regional alteration. Calcite is the major gangue phase within the stratabound deposits, which tend to lack dolomite/ankerite and siderite. Carbonates precipitated from hydrothermal ore fluids are typically Mn-rich, up to 3.55 at. \% in siderite, 2.27 at. \% in dolomite/ankerite, and 1.92 at. \% in calcite. In contrast, calcite related to very low-grade metamorphism or regional low-temperature alteration is Mn-poor but sometimes Mg-rich, possibly related to a higher temperature of formation. Chemical zonation was observed in the hydrothermal carbonates, although no unique pattern and chemical evolution was observed. This study suggests that the chemical composition of carbonates, especially the Mn content, could be a useful vector within ore-forming hydrothermal systems, and therefore constitutes a possible tool in geochemical exploration. Furthermore, Mn-poor calcites detected in some deposits are suggested to be linked with a later episode, maybe suggesting a predominance of meteoric waters, being not related to the main ore stage formation, thus avoiding misunderstanding of further isotopic studies.
\end{abstract}

Keywords: hydrothermal; gangue; Mn; carbonate; Spain; Chile

\section{Introduction}

Carbonates are commonly present as part of the gangue in hydrothermal deposits associated with quartz, phyllosilicates, and barite. Carbonates are a focus of interest to researchers investigating ore-forming systems; fluid inclusion and isotopic data $(C$, $\mathrm{O}, \mathrm{Sr}, \mathrm{Pb}$ ) can give important information on the provenance of hydrothermal fluids (e.g., [1-13]). However, only limited works on the composition of carbonates in ore-forming hydrothermal environments are available (e.g., [6,14-17]). Nevertheless, these authors suggest a possible association of an elevated Mn content in carbonates with ore-forming hydrothermal fluids, and Mn has been used as an index of such activity in whole-rock compositions (e.g., [18,19]). Furthermore, recent works in low-temperature non-ore systems 
have demonstrated the usefulness of applying a full range of techniques in carbonate study, including elemental analysis of carbonates [20-22]. Here, we systematically characterize the mineralogy and composition of carbonate associations from contrasting ore-related hydrothermal environments, the corresponding volcanic host rocks, and zones of weak alteration in Cabo de Gata Volcanic Belt in southeastern Spain and the Costal Range of central Chile. These new geochemical data suggest that hydrothermal carbonates related to ore formation can be clearly distinguished from sedimentary marine, metamorphic, and low-temperature carbonates. Furthermore, routine EPMA (Electron Probe Micro Analyser) chemical analysis of carbonates in ores could help to interpret their geochemical and isotopic composition by confirming the carbonates under investigation are directly related to ore-forming hydrothermal fluids.

\section{Samples and Analytical Techniques}

Samples for this study were collected from within volcanic and volcano-sedimentary terrains of Cretaceous-Cenozoic age (Table 1, Figure 1). In the Cabo de Gata Volcanic belt (southeast Spain), the Au-Cu Palai-Islica deposit was investigated. In the La Serena $-29^{\circ} 3^{\prime}-30^{\circ} 0^{\prime}$ S- and Melipilla $-33^{\circ} 50^{\prime}$ S- regions of Chile, several types of deposits were investigated, including: volcanic-hosted $\mathrm{Au}-\mathrm{Cu}$ epithermal at El Dorado in La Serena; "Chilean Manto-type" Cu(-Ag), at Quebrada Marquesa in La Serena and Melipilla; stratabound Mn-rich hydrothermal deposit, at Quebrada Marquesa in La Serena; and Ag-Ba epithermal veins at Talcuna in La Serena.

In addition to mineralized samples, carbonate samples were also collected from unmineralized host rocks close to each deposit in SE Spain and Chile affected by regional low-temperature hydrothermal alteration, and very low-grade metamorphism.

Petrographic observations were done using a transmitted and reflected light microscope and scanning electron microscopy (SEM) (ZEISS DSM 950). The geochemical composition of the studied minerals was characterized using an electron microprobe analyzer (EPMA) (CAMECA SX-50) of the "Centro de Instrumentación Científica" from the University of Granada. EPMA and SEM back-scattered images were used to determine the chemical composition and zonation of selected carbonates. A total of 559 micro-analyses of carbonate were made with EPMA. The operating conditions were $20 \mathrm{kV}$ accelerating potential, $20 \mathrm{nA}$ beam current, $60 \mathrm{~s}$ X-ray peak and background acquisition times, and a specify wide beam in order to avoid damage to the crystal during analysis. Natural and artificial standards were used to calibrate quantitative analyses. The detection limit of different elements was around $0.05 \mathrm{wt} . \%$. 
Table 1. Summary of the main characteristics of the mineral deposits that hosts the studied samples.

\begin{tabular}{|c|c|c|c|c|c|c|}
\hline & $\begin{array}{c}\text { Palai-Islica } \\
\text { (Spain) }\end{array}$ & $\begin{array}{l}\text { El Dorado } \\
\text { (Chile) }\end{array}$ & $\begin{array}{l}\text { Quebrada Marquesa } \\
\text { (Chile) }\end{array}$ & $\begin{array}{c}\text { Quebrada Marquesa } \\
\text { (Chile) }\end{array}$ & $\begin{array}{c}\text { Arqueros } \\
\text { (Chile) }\end{array}$ & $\begin{array}{c}\text { Melipilla } \\
\text { (Chile) }\end{array}$ \\
\hline Deposit type & $\begin{array}{l}\text { Epithermal Au-Cu } \\
\text { volcanic-hosted }\end{array}$ & $\begin{array}{l}\text { Epithermal Au-Cu } \\
\text { volcanic-hosted }\end{array}$ & $\begin{array}{c}\text { "Chilean Manto-type" } \\
\mathrm{Cu}(-\mathrm{Ag})\end{array}$ & Stratabound Mn & Ag-Ba epithermal veins & $\begin{array}{c}\text { "Chilean Manto-type" } \\
\mathrm{Cu}(-\mathrm{Ag})\end{array}$ \\
\hline Tectonic Setting & $\begin{array}{c}\text { Extension after Alpine } \\
\text { orogenesis }\end{array}$ & $\begin{array}{l}\text { Compresional, arc } \\
\text { setting }\end{array}$ & $\begin{array}{l}\text { Extension, intra-arc } \\
\text { basin }\end{array}$ & $\begin{array}{l}\text { Extension, intra-arc } \\
\text { basin }\end{array}$ & $\begin{array}{l}\text { Extension, intra-arc } \\
\text { basin }\end{array}$ & $\begin{array}{c}\text { Extension, intra-arc } \\
\text { basin }\end{array}$ \\
\hline Morphology & $\begin{array}{l}\text { Stockwork veins (and } \\
\text { replacement) }\end{array}$ & Stockwork veins & $\begin{array}{l}\text { Veins and replacement } \\
\text { (stratabound) }\end{array}$ & Stratiform & Veins & $\begin{array}{l}\text { Veins and replacement } \\
\text { (stratabound) }\end{array}$ \\
\hline Host rock & $\begin{array}{l}\text { Andesites, dacites } \\
\text { (Carboneras C-3 } \\
\text { Formation) }\end{array}$ & $\begin{array}{l}\text { Andesites (Los Elquinos } \\
\text { Formation) }\end{array}$ & $\begin{array}{l}\text { Andesites, basaltic } \\
\text { andesites (Quebrada } \\
\text { Marquesa Formation) }\end{array}$ & $\begin{array}{c}\text { Andesites, basaltic } \\
\text { andesites (Arqueros } \\
\text { Formation and Quebrada } \\
\text { Marquesa Formation) }\end{array}$ & $\begin{array}{c}\text { Andesites, basaltic } \\
\text { andesites (Arqueros } \\
\text { Formation) }\end{array}$ & $\begin{array}{c}\text { Andesites, basaltic } \\
\text { andesites, limestones (Lo } \\
\text { Prado and Veta Negra } \\
\text { Formations) }\end{array}$ \\
\hline $\begin{array}{l}\text { Hydrothermal } \\
\text { alteration }\end{array}$ & $\begin{array}{l}\text { Pervasive (argillic to } \\
\text { propylitic) }\end{array}$ & $\begin{array}{l}\text { Pervasive (argillic to } \\
\text { propylitic?) }\end{array}$ & $\begin{array}{c}\text { Not well developed. } \\
\text { Associated with very } \\
\text { low-grade assemblages? }\end{array}$ & $\begin{array}{l}\text { Not well developed. } \\
\text { Associated with very } \\
\text { low-grade assemblages }\end{array}$ & $\begin{array}{c}\text { Not well developed. } \\
\text { Associated/obliterated? } \\
\text { by very low-grade } \\
\text { assemblages }\end{array}$ & $\begin{array}{l}\text { Not well developed. } \\
\text { Associated with very } \\
\text { low-grade assemblages }\end{array}$ \\
\hline $\begin{array}{c}\text { Ore } \\
\text { Mineralogy }\end{array}$ & $\begin{array}{l}\text { Pyrite, chalcopyrite } \pm \\
\text { sphalerite, galena (gold, } \\
\text { Ag-bearing minerals) }\end{array}$ & $\begin{array}{l}\text { Pyrite, chalcopyrite } \pm \\
\text { fahlore (gold) }\end{array}$ & $\begin{array}{c}\text { Chalcopyrite, bornite } \pm \\
\text { sphalerite, galena, } \\
\text { chalcocite (fahlore, } \\
\text { stromeyerite) }\end{array}$ & $\begin{array}{l}\text { Braunite, piemontite } \\
\text { (pyrolusite) }\end{array}$ & $\begin{array}{c}\mathrm{Ag}, \mathrm{Ag} \text { sulfide, fahlore, } \\
\text { bornite, chalcocite }\end{array}$ & $\begin{array}{l}\text { Chalcopyrite, bornite, } \\
\text { pyrite } \pm \text { chalcocite } \\
\text { (fahlore, arsenopyrite...) }\end{array}$ \\
\hline Age & Tortonian & $\begin{array}{l}\text { Upper Creteceous } \\
\text {-Paleocene? }\end{array}$ & Albian-Cenomanian & Lower Cretaceous & Albian-Cenomanian? & Albian-Cenomanian \\
\hline Location & $\begin{array}{l}\sim 1^{\circ} 55^{\prime} \text { W Long., } \sim 37^{\circ} 00^{\prime} \\
\text { N Lat. }\end{array}$ & $\begin{array}{l}\sim 70^{\circ} 44^{\prime} \text { W Long., } \\
\sim 29^{\circ} 47^{\prime} \text { S Lat. }\end{array}$ & $\begin{array}{l}\sim 70^{\circ} 52^{\prime} \text { W Long., } \\
\sim 29^{\circ} 54^{\prime} \text { S Lat. }\end{array}$ & $\begin{array}{l}\sim 70^{\circ} 54^{\prime} \text { W Long., } \\
\sim 29^{\circ} 54^{\prime} \text { S Lat. }\end{array}$ & $\begin{array}{l}\sim 70^{\circ} 54^{\prime} \text { W Long., } \\
\sim 29^{\circ} 51^{\prime} \text { S Lat. }\end{array}$ & $\begin{array}{l}\sim 71^{\circ} 01^{\prime} \text { W Long., } \\
\sim 33^{\circ} 49^{\prime} \text { S Lat. }\end{array}$ \\
\hline References & {$[23-28]$} & {$[29]$} & {$[25,30-33]$} & {$[25,30-32]$} & {$[25,30-32]$} & {$[33]$} \\
\hline
\end{tabular}




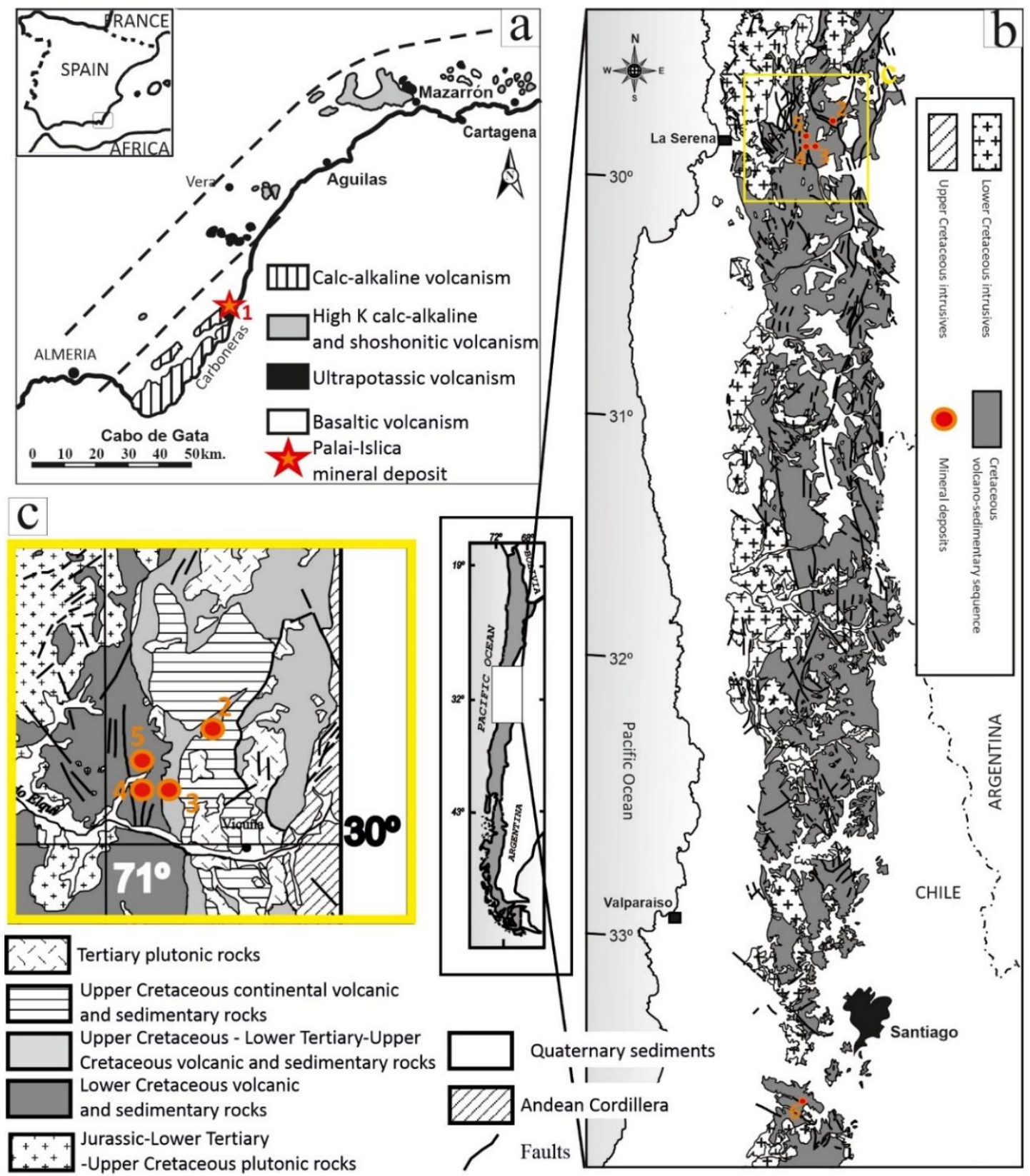

Figure 1. Geological framework of the studied areas. (a) Simplified geological map of the Cabo de Gata-Cartagena volcanic province in SE of Spain, with (1) the Palai-Islica, epithermal Au-Cu volcanic-hosted deposit, location (adapted from [23]). (b) Simplified geological map of the Lower Cretaceous belt in the Coastal Range of north-central and central Chile showing the studied deposits: (2) El Dorado-epithermal Au-Cu volcanic-hosted-, (3) Quebrada Marquesa-“ “Chilean Manto-type" Cu(-Ag)-, (4) Quebrada Marquesa-Stratabound Mn-, (5) Arqueros-Ag-Ba epithermal veins-, (6) Melipilla"Chilean Manto-type" Cu(-Ag)-. (c) Geological map of La Serena area, where the majority of the studied deposits are located (adapted from $[29,33])$.

\section{Geological Setting and Mineralogical Features}

\subsection{Palai-Islica, Southeastern Spain}

Palai-Islica is an intermediate and high sulphidation Au-Cu epithermal deposit hosted by hydrothermally altered Miocene calc-alkaline andesitic to dacitic rocks of the Cabo de Gata-Cartagena volcanic belt [23,28] (Table 1, Figure 1). This belt formed during extension of a thickened lithosphere during the Betic Orogeny (e.g., [34]). The mineralization consists 
of quartz veins with sulfides, some cases forming stockwork structures, and as replacement ore in zones of intense silicification. Details of the ore mineralogy and geochemistry of the deposit can be found in $[23,24,26,27,35]$. Quartz and white mica are the main gangue phases. Dolomite/ankerite and siderite, which are also common minerals, appear later in the paragenetic sequence, as micro-veinlets (Figure 2a), breccia cements of coarse equigranular grains, and sometimes rhombohedral crystals in the mineralized veins. Disseminated granular dolomite is also present in the hydrothermally altered volcanic host rocks, mostly replacing hornblende, pyroxenes, and plagioclase phenocrysts (Figure 2b). In addition, there is a regional replacement of mafic and plagioclase phenocrysts in volcanic rocks of the Cabo de Gata-Cartagena volcanic belt by calcite. Locally, unmineralized dolomite+calcite veins crosscut the volcanic rocks, and contain clasts of unaltered volcanic phenocrysts (Figure 2c). Toward the margin of the deposit, in the zone of propylitic alteration zone, dolomite is observed, replacing calcite (Figure 2d).

\subsection{El Dorado, La Serena, Central Chile}

El Dorado is an intermediate sulfidation $\mathrm{Au}-\mathrm{Cu}$ epithermal deposit hosted by andesitic rocks of the Coastal Range of central Chile [29] (Table 1, Figure 1). It is located within the Upper Cretaceous Los Elquinos Formation (continental volcanoclastic dacites and andesites), associated with a zone of intense hydrothermal alteration. The available data for this Au$\mathrm{Cu}$ prospect suggest that the style of mineralization is similar to the Palai-Islica deposit [25]. Ankerite is the predominant carbonate mineral found at El Dorado; ankerite in veins is subordinate to quartz and is paragenetically later than quartz and the main group of sulfides.

\subsection{Quebrada Marquesa and Arqueros, La Serena, Central Chile}

"Chilean Manto-type" Cu(-Ag), stratiform Mn, and Ag-Ba vein deposits coexist in the Coastal Range in the La Serena region within volcano and volcano-sedimentary sequences of Lower Cretaceous age [30,36,37] (Table 1, Figure 1). The Arqueros Formation (an Hauterivian-Barremian sequence of porhyric andesites and marine limestones) hosts Ag-Ba vein deposits, whereas the Quebrada Marquesa Formation (an Upper Barremian-Albian volcano-sedimentary sequence of andesites and continental sedimentary rocks, with minor intercalations of marine limestones and evaporites) hosts "Chilean Manto-type" $\mathrm{Cu}(-\mathrm{Ag})$ deposits. In addition, there are stratiform Mn deposits (oxides and silicate type) in the upper parts of the Arqueros Formation and mainly in the lower part of the Qubrada Marquesa Formation. Although the ore mineralogy of these deposits shows differences among them, they all share a gangue mineralogy dominated by calcite and barite $[25,33]$ (Figure 2e). The host volcanic rocks range in composition from high-K calc-alkaline basaltic andesites to andesites [38], which underwent extensive very low-grade metamorphism [39], with amygdules commonly filled by prehnite and coarse calcite (Figure 2f).

\subsection{Melipilla, Central Chile}

"Chilean Manto-type" $\mathrm{Cu}(-\mathrm{Ag})$ mineralization in Melipilla occurs in limestones, mudstones and andesites of the Lo Prado (Berrian-Hauterivian) and Veta Negra formations (Hauterivian-Barremian), part of the Coastal Range [33]. Two ore types exist: a low-grade, bornite-chalcocite disseminated mineral association and a sulfide-rich polymetallic mineral association [33]. Both styles of mineralization contain calcite as a gangue phase. However, in the low-grade disseminated mineralization, it appears as void infilling (late phase), subordinate to quartz, whereas in the sulfide-rich polymetallic association, it is the main gangue phase (Figure 2g,h). Clasts of limestone host rocks within the mineralization are observed in addition to calcite gangue (Figure $2 \mathrm{~g}$ ). The andesitic host rocks were subject to very low-grade metamorphism, with calcite a common mineral of this regional alteration in the form of microveins and amygdule infill. 

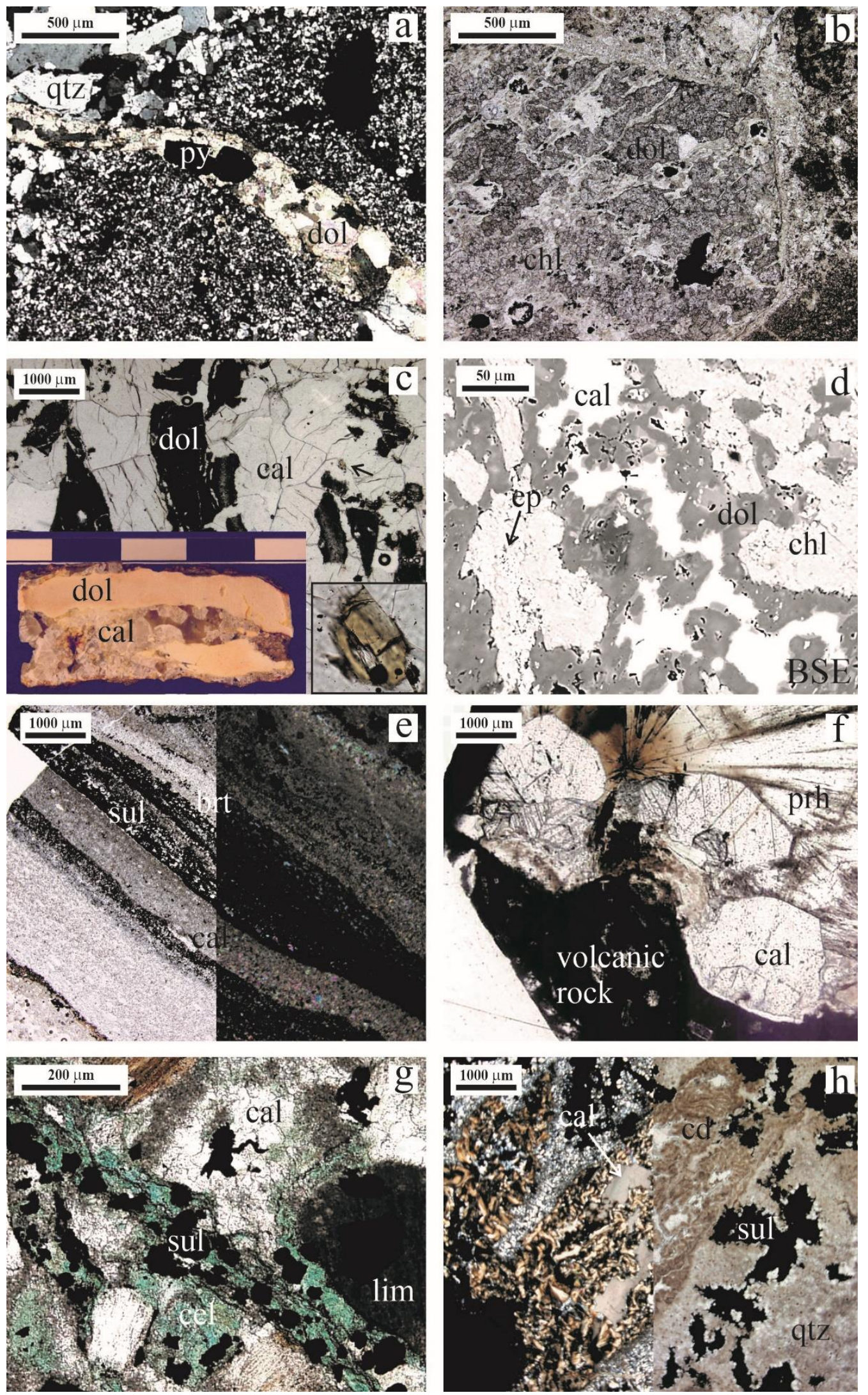

Figure 2. Transmitted light photomicrographs, back-scattered electron (BSE) images, and hand specimen photographs of different carbonates associated with hydrothermal ore deposits and associated host rocks. (a) Ore-related dolomite/ankerite (dol) microvein with pyrite (py) crosscutting an earlier quartz vein, in the Au-Cu epithermal Palai-Islica (SE Spain) deposit. 
(b) Dolomite/ankerite (dol) and chlorite (chl) replacing volcanic hornblende in pervasive hydrothermal alteration of andesites and dacites in Palai-Islica. (c) Unmineralized dolomite (dol) + calcite (cal) veins crosscutting the volcanic rocks of the Cabo de Gata volcanic belt with unaltered hornblende clasts (indicated by an arrow). (d) Dolomite (dol), associated with epidote (ep) and chlorite (chl), replacing calcite (cal) in distal, propylitic-type, hydrothermal alteration of the Palai-Islica deposit. (e) Banded vein of sulfides (sul) with calcite (cal) and barite (brt) in the Quebrada Marquesa (La Serena, central Chile) "Chilean Manto-type" Cu(-Ag) deposit. (f) Amygdule infilling of calcite (cal) and prehnite (prh) related to very low-grade metamorphism in an andesite from the La Serena area. (g) Polymetallic-ore association at Melipilla "Chilean Manto-type" $\mathrm{Cu}(-\mathrm{Ag})$ mineralization, with calcite (cal) and celadonite (cel) associated with sulfides and with clasts of host limestone (lim). (h) Late calcite (cal) filling associated with low-grade disseminated sulfide (sul) ore.

\section{Elemental Composition of Carbonate Minerals}

\subsection{Epithermal Au-Cu Volcanic-Hosted Deposits, Palai-Islica and El Dorado}

The results of the EPMA analyses of dolomite/ankerite for the Palai-Islica and El Dorado deposits are summarized in Table S1 and plotted in Figures 3-5. In the PalaiIslica deposits, there is a large range of Ca (5.43-11.05 at. \%), Mg (5.69-10.16 at. \%), Fe (0.03-4.41 at. \%), and Mn (0.18-2.27 at. \%), with clear chemical differences between different generations of dolomite/ankerite. For example, dolomite/ankerite in the orebody has the widest range of Fe and Mn values, with a heterogeneous spatial distribution and a long tail to higher Fe and Mn contents toward the ankerite field. Dolomite from barren veins in volcanic rocks shows the lowest Fe and Mn contents (below 0.25 at. \%), and is quite homogeneous (Figure 4). Dolomite in the hydrothermal alteration shows a considerable compositional range (up to 1.75 at. \% Fe and 1.04 at. \% Mn, Figure 4). Nevertheless, the modes for the Fe and Mn contents obtained for dolomite within the hydrothermal alteration coincide with the modes for Fe and Mn obtained from dolomite in the orebody (Figure 4). The Fe and Mn contents are approximately proportional at 2:1 (Figure 5a), with the majority of the analysis showing an inverse correlation between $\mathrm{Fe}+\mathrm{Mn}$ and $\mathrm{Mg}$, with the exception of carbonates, showing the highest Fe+Mn contents (Figure 5b).

Siderite crystal occurs as an accessory phase in the orebody. It shows a variable composition (Table S1, Figure 3). The major elements, Mg (0.19-3.58 at. \%), Mn (1.11-3.55 at. \%), and $\mathrm{Ca}(0.10-2.54$ at. \%), are approximately proportional to the Fe content, which ranges between 9.46 and 16.83 at. \%.

The calcite composition (Table S1, Figure 3) reveals concentrations of Fe $(0-0.75$ at. \%), Mg (0.01-0.52 at. \%), and Mn (0.00-0.30 at. \%), which differ among sample sites. Calcite from regions of propylitic hydrothermal alteration shows significantly higher Mn contents $(0.07-0.30$ at. $\%)$ than for regional alteration and barren veins $(<0.05$ at. $\%)$. The calcite from these systems also shows a relatively high abundance of Fe and $\mathrm{Mg}$, with a correlation between the $\mathrm{Mg}$ and the Mn and Fe contents (Figure $5 \mathrm{c}, \mathrm{d}$ ).

Back-scattered SEM images of Palai-Islica carbonates reveal chemical zonation in dolomite/ankerite crystals from the orebody (Figure 6), which typically depict a concentric pattern, in some cases oscillatory, with a dark core and a bright rim. This pattern reflects a rim depleted in $\mathrm{Mg}$ and enriched in Fe and, in some cases, Mn. The composition of a single crystal can almost record the entire chemical variation observed for a given population (Figures 4 and 6).

Ankerite from the El Dorado orebody has a composition (Table S1, Figure 3) with similarities to dolomite/ankerite of Palai-Islica. The range of Ca (7.57-11.06 at. \%), Fe (2.36-5.29 at. \%), and Mn (0.32-1.02 at. \%) overlaps the range of data from the PalaiIslica carbonates. Although carbonates with a similar Fe content from El Dorado show an increased Ca content and less Mn than observed in the Palai-Islica samples, no proportional relationship between Fe and $\mathrm{Mn}$ is observed in El Dorado ankerites. In addition, the Mg content (3.45-6.47 at. \%) of ankerite from El Dorado is consistently lower than in Palai-Islica ankerite. 
Back-scattered SEM images of ankerite at El Dorado reveal irregular and oscillatory chemical zonation (Figure 7). The oscillatory rims have a relatively low Fe content, whereas irregularly zoned cores have a significantly higher Fe and Mn content.

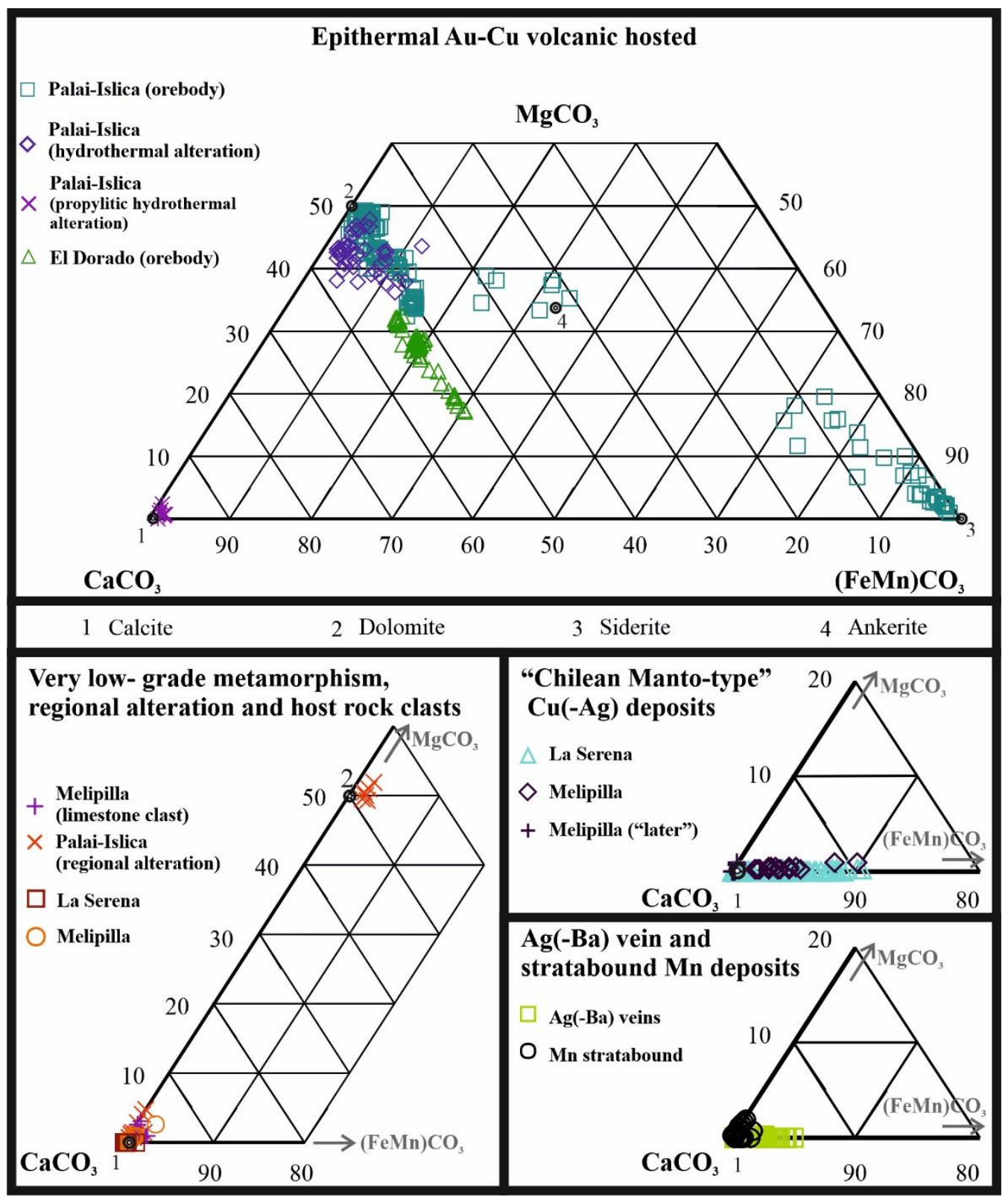

Figure 3. Triangular plot $\left(\mathrm{CaCO}_{3}-\mathrm{MgCO}_{3}-\mathrm{FeCO}_{3}+\mathrm{MnCO}_{3}\right)$ showing the major molar composition of analyzed carbonates. According to the carbonate type in each location, only a portion of the triangles is shown. 

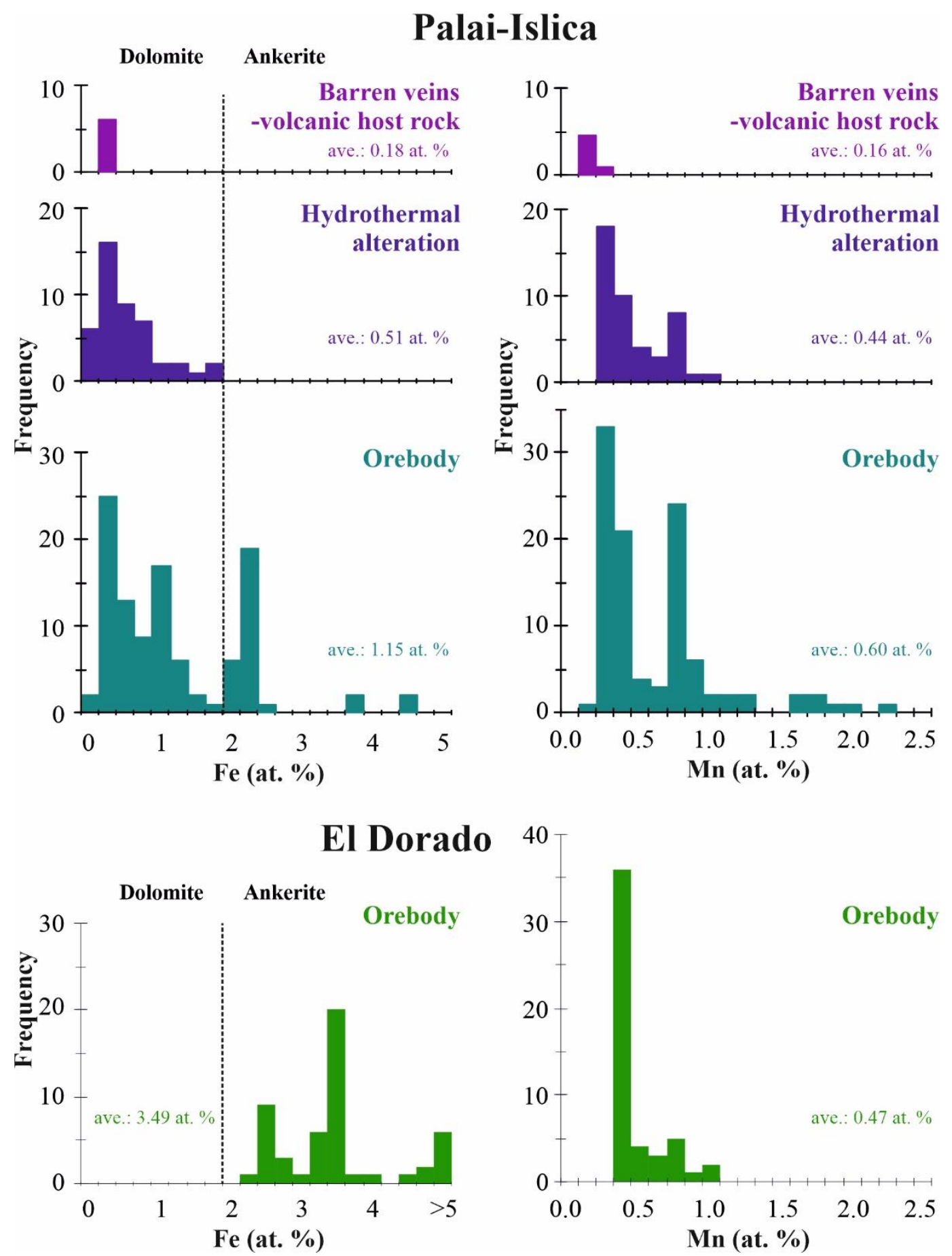

Figure 4. Frequency histograms for the Fe and $\mathrm{Mn}$ content in atomic \% for the dolomite/ankerite analyzed from the Au-Cu epithermal deposit (Palai-Islica-SE Spain, and El Dorado-central Chile). 

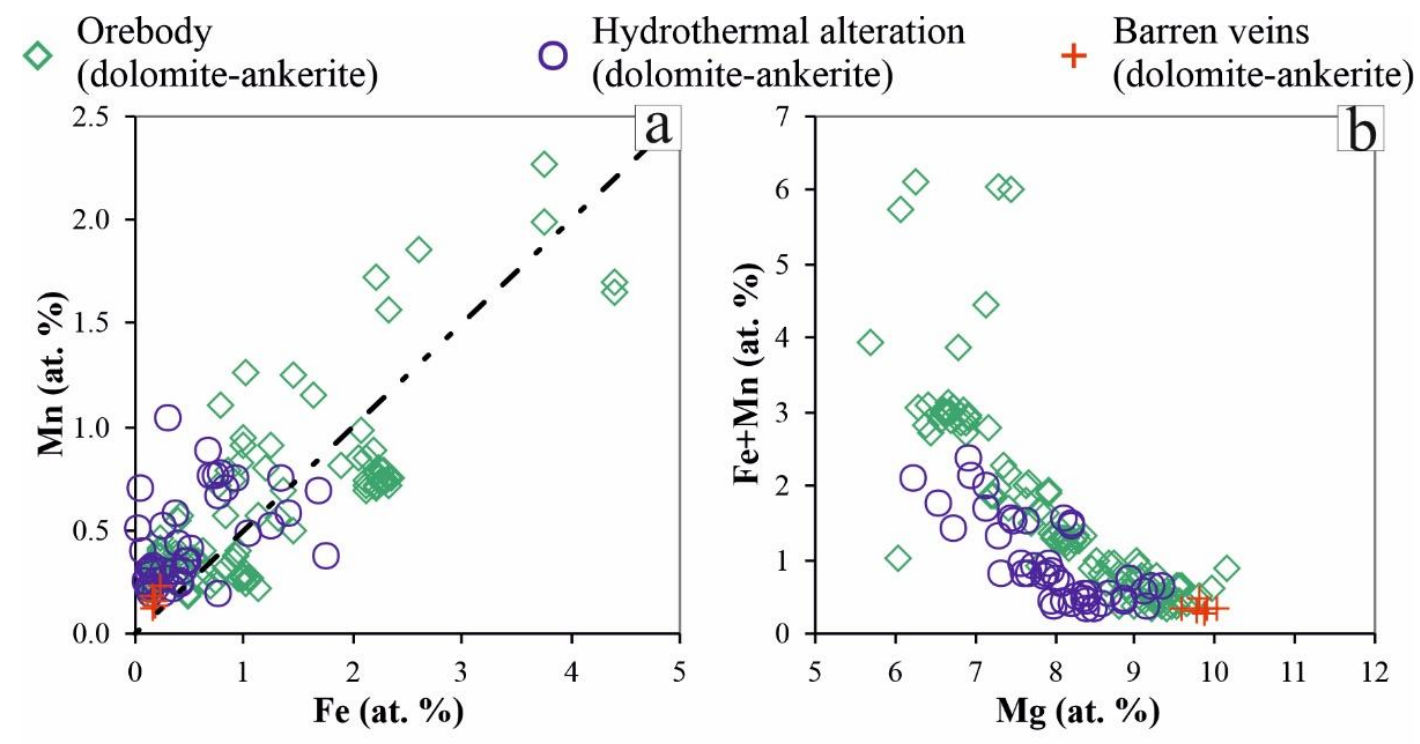

$\begin{aligned} & \begin{array}{l}\text { Propylitic hydrothermal } \\ \text { alteration (calcite) }\end{array} \\ & 0.3\end{aligned} \quad+\begin{aligned} & \text { Regional alteration } \\ & \text { (calcite) } \\ & \text { (calcite) }\end{aligned}$
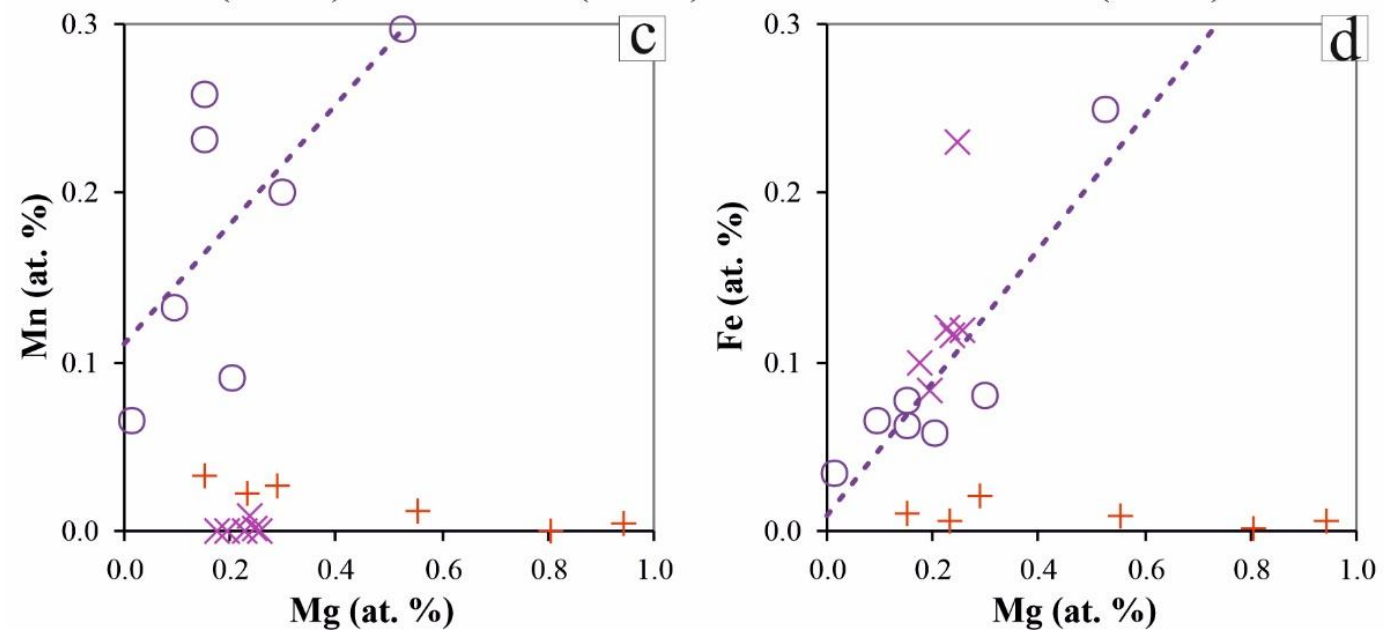

Figure 5. Composition of carbonates from Palai-Islica area (SE Spain): (a) Fe vs. Mn and (b) Mg vs. Fe+Mn in dolomite/ankerite: orebody, hydrothermal alteration, and barren veins in the volcanic rocks of the Cabo de Gata-Cartagena volcanic belt belonging to a regional alteration. The dotted line marks in (a) a Fe:Mn relation of 2:1. (c) Mg vs. Mn and (d) $\mathrm{Mg}$ vs. Fe in calcite: propylitic hydrothermal alteration, regional alteration in the volcanic rocks of the Cabo de Gata volcanic belt, and barren veins in the volcanic rocks of the Cabo de Gata volcanic belt. The dotted colored lines mark, respectively, in (c) and (d) the correlation between $\mathrm{Mg}$ and $\mathrm{Mn}\left(\mathrm{r}^{2}=0.46\right)$ and $\mathrm{Mg}$ and $\mathrm{Fe}\left(\mathrm{r}^{2}=0.85\right)$ in calcite from the propylitic hydrothermal alteration. 

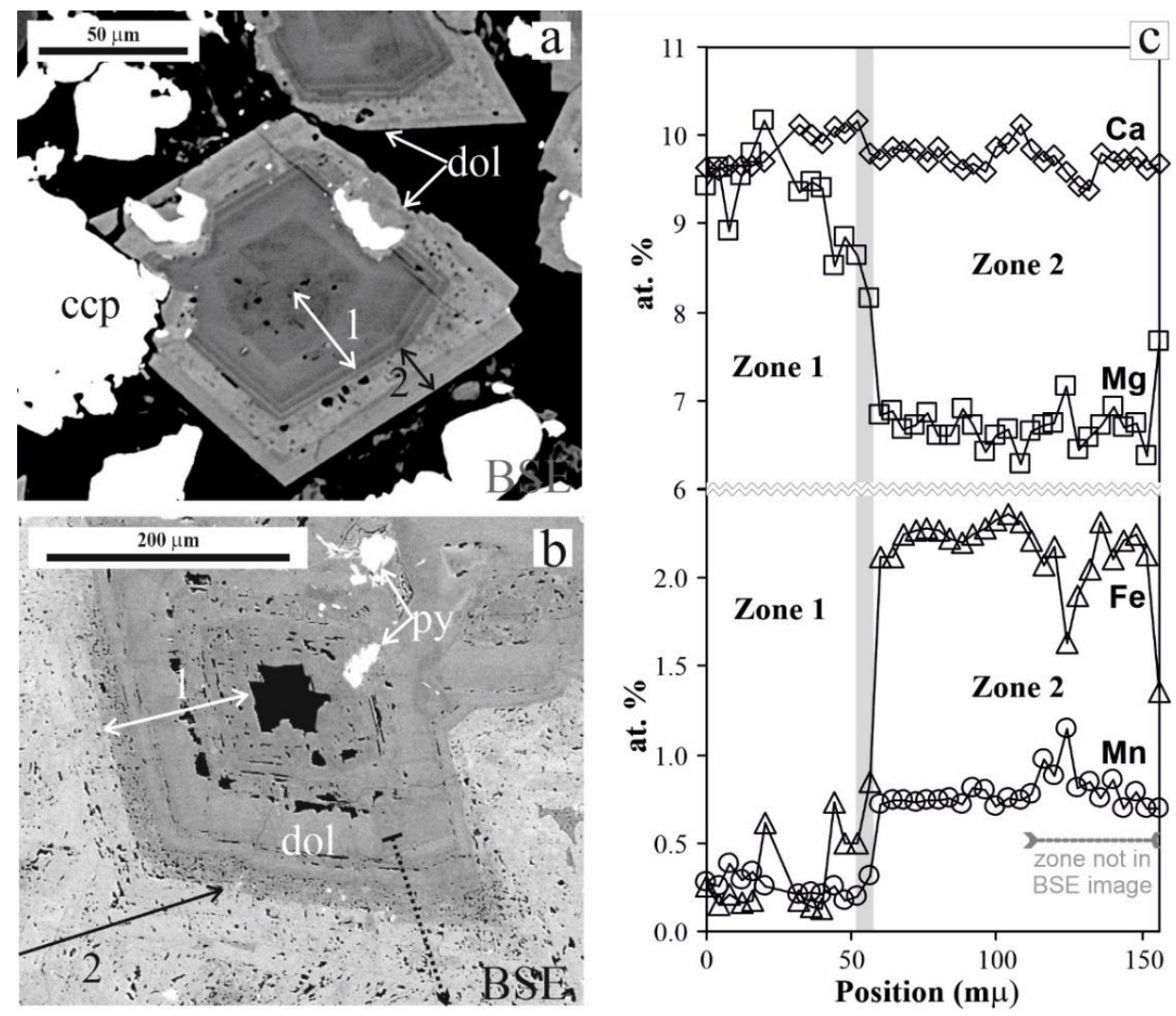

Figure 6. Back-scattered electron (BSE) images $(\mathbf{a}, \mathbf{b})$ of zoned dolomite/ankerite from the Palai-Islica orebody (SE Spain) in which two main zones 1 (earlier and darker in BSE), and 2 (later and brighter in BSE) are distinguished. In (c), a profile through the crystal of picture $\mathrm{b}$ (indicated by a dotted line, which end is out of the picture) is shown, being represented $\mathrm{Mg}$, $\mathrm{Ca}, \mathrm{Fe}$, and $\mathrm{Mn}$ atomic \% contents.
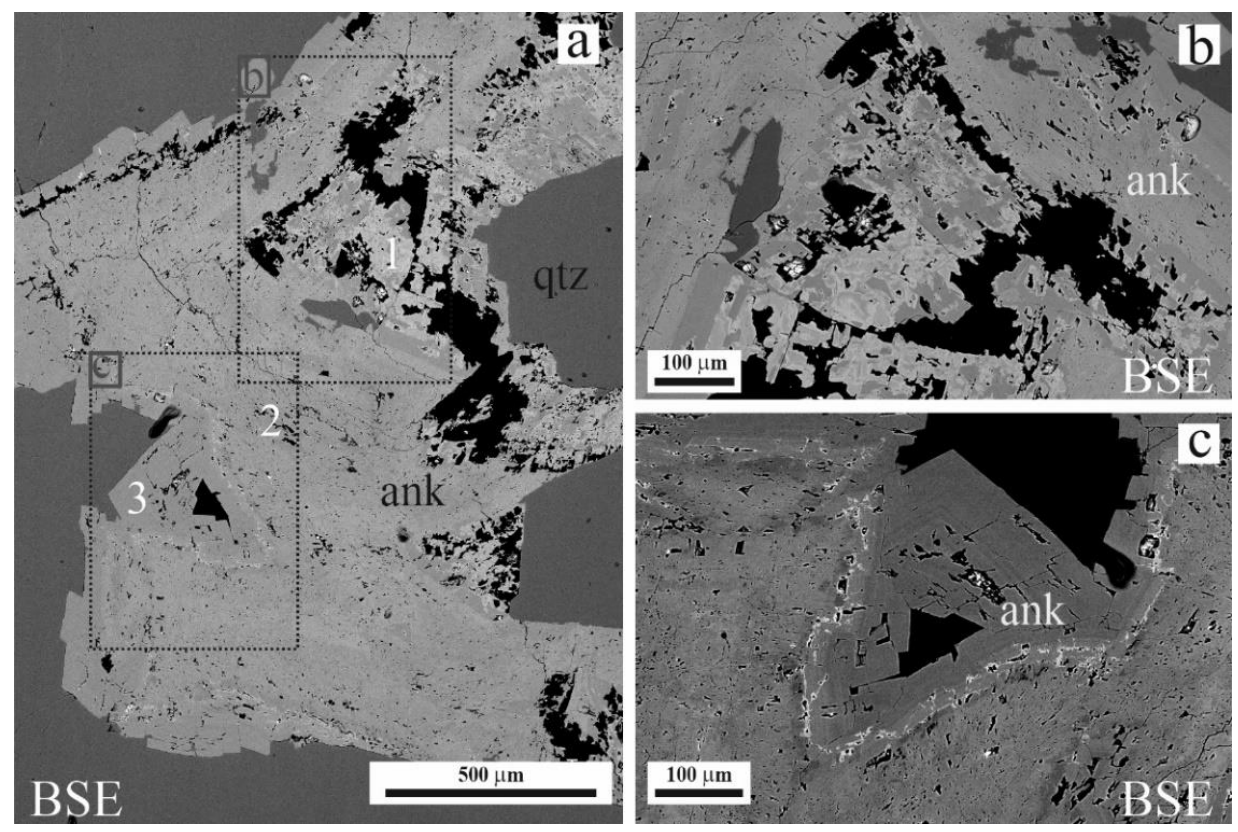

Figure 7. Back-scattered electron (BSE) images of zoned ankerite aggregate crystals in the El Dorado Au-Cu orebody (central Chile). Three zones are observed: (1) highly irregular zoned cores, with the highest Fe and Mn content; (2) porous weak zoned zone and overgrowth; with (3) weak oscillatory zonations and the lowest Fe and Mn content. Images (b,c) show details of the rectangle areas of image (a). 


\section{2. "Chilean Manto-Type" Cu(-Ag) Deposits, Quebrada Marquesa in La Serena and Melipilla}

The composition of calcite, a major gangue phase in these deposits, is compiled in Table S2 and Figures 3 and 8. Calcite from the Quebrada Marquesa, La Serena, and Melipilla polymetallic deposits shows relatively high Mn contents (0.01-1.92 at. \%; average 0.57 at. \%), and low Fe contents (0.00-0.45 at. \%; average 0.09 at. \%). The amounts of Fe and Mn correlate poorly (Figure 8a), but with a higher slope to the data from the Melipilla polymetallic association, compared to the Quebrada Marquesa data. The Melipilla data also show lower Fe contents than the polymetallic association at Quebrada Marquesa (Figure 8a). The level of $\mathrm{Mg}$ in calcite from both localities broadly correlates with $\mathrm{Mn}+\mathrm{Fe}$ (Figure 8b), although calcite from the Melipilla polymetallic association is richer in $\mathrm{Mg}$ than in Quebrada Marquesa (0.03-0.18 at. \% and 0.00-0.05 at. \%, respectively). It is noteworthy that the lowest $\mathrm{Mn}$ and Fe contents were recorded in late calcite from the Melipilla low-grade disseminated mineral association, but with a slightly elevated $\mathrm{Mg}$ content of $0.00-0.16$ at. \% (Figure 8a,b). Finally, calcite from limestone host rock clasts within the mineralization are also $\mathrm{Mn}$ and Fe poor (Mn: 0.01-0.28 at. \%; Fe: $0.01-0.11$ at. \%) but with a relatively high $\mathrm{Mg}$ content (0.06-0.63 at. \%).

Calcite from these "Chilean Manto-type" $\mathrm{Cu}(-\mathrm{Ag})$ deposits is also commonly zoned, as shown by the back-scattered SEM images. The zonation is complex, commonly with a morphology resembling "caries" textures or forming a patchwork (Figure 9). Backscattered images show that paragenetically late calcite is commonly dark and Mn- and Fe-poor, compared to the initial or earlier calcite, which itself has a variable Mn-Fe content.

\subsection{Other Deposits: Ag-Ba Vein and Stratabound Mn Deposits (Quebrada Marquesa and Arqueros in La Serena)}

Calcite compositions (Table S3) from a stratabound Mn deposit in Quebrada Marquesa are characterized by low $\mathrm{Mn}$ and Fe contents (Mn: 0.00-0.32 at. \%; Fe: 0.00-0.02 at. \%, Figure $8 \mathrm{c}, \mathrm{d})$ and high $\mathrm{Mg}$ contents (0.00-0.36 at. \%). In contrast, calcite from the Ag-Ba veins in Arqueros has relatively high $\mathrm{Mn}$ and Fe (Mn: 0.03-0.94 at. \%; Fe: 0.00-0.12 at. \%) with a low $\mathrm{Mg}$ content $(0.00-0.03$ at. \%, Figure $8 \mathrm{c}, \mathrm{d})$. Notably, calcite from veins richer in total metal content (mainly $\mathrm{Cu}$, although poorer in $\mathrm{Ag}$ ) have appreciable higher $\mathrm{Fe}$ and $\mathrm{Mn}$ contents (Mn: 0.05-0.94 at. \%; Fe: 0.00-0.12 at. \%, Figure 8c,d) compared to calcite from veins with lower total metal contents (Mn: 0.03-0.27 at. \%; Fe: 0.00-0.02 at. \%, Figure 8c,d). Back-scattered SEM images of calcite from the Ag-Ba veins resemble carbonate crystals from the "Chilean Manto-type" $\mathrm{Cu}(-\mathrm{Ag})$ deposits, with similar "caries"-like textures (Figure 10). Truncations of oscillatory banded calcite are also observed. In the case of the Mn deposits, bright cores (Mn-Fe rich) are embedded in dark calcite with a tendency toward a lower $\mathrm{Mn}(-\mathrm{Fe})$ content as precipitation progresses.

\subsection{Very Low-Grade Metamorphism (La Serena and Melipilla)}

Calcite filling vacuoles, in veins, or as replacement of phenocrysts associated with low-grade metamorphic assemblages in the volcanic rocks show compositions (Table S4) characterized by very low Mn contents $(0.00-0.08$ at. \%, Figure 8e,f) both in La Serena and Melipilla. The $\mathrm{Mg}$ content is generally very low at La Serena (0.00-0.01 at. \%) but relatively high (0.00-0.46 at. \%) at Melipilla (Figure 8f). 
"Chilean Manto-type" Cu(-Ag) deposits

Quebrada Marquesa

(polymetallic mineral association)

Ag-Ba vein and stratabound Mn deposits $\mathrm{Ag}-\mathrm{Ba}$, Arqueros

relatively base-metal rich

$\triangle$ relatively base-metal poor

Very low-grade metamorphism

* La Serena
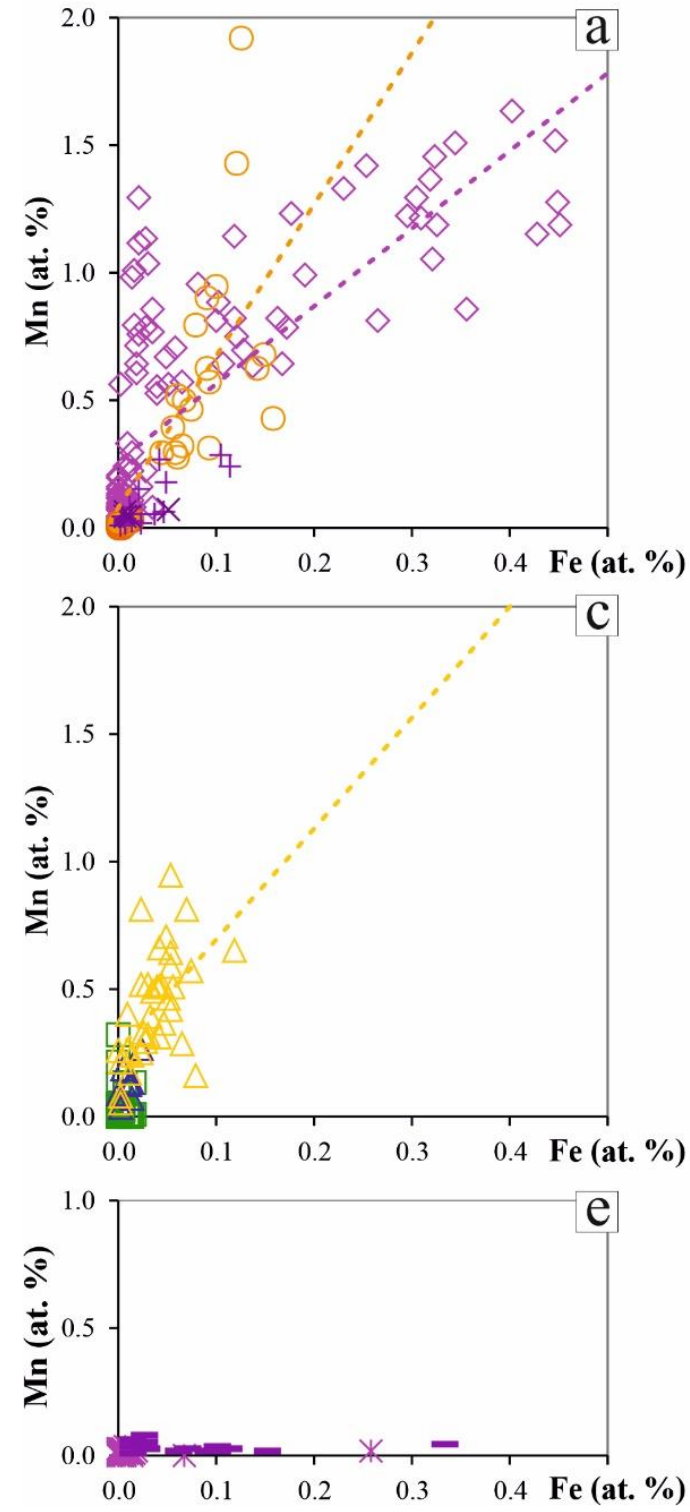

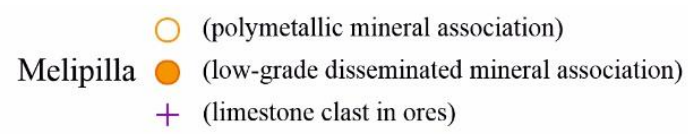

Mn, Quebrada Marquesa

- Melipilla
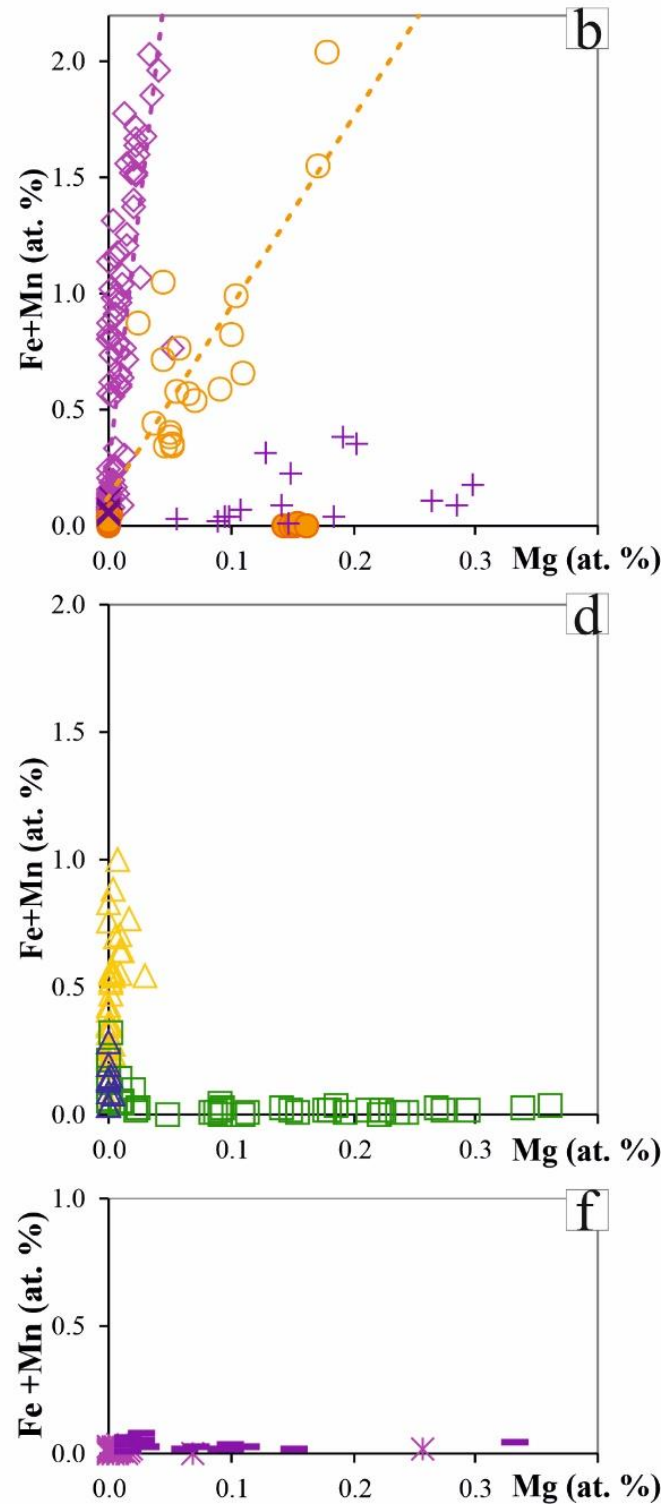

Figure 8. Fe vs. $\mathrm{Mn}$ and $\mathrm{Mg}$ vs. Fe+Mn in atomic \% showing the composition of calcite from different mineralizations/very low-grade metamorphism in central Chile: $(\mathbf{a}, \mathbf{b})$ "Chilean Manto-type" Cu(-Ag) deposits (Quebrada Marquesa -La Serenaand Melipilla, central Chile): Quebrada Marquesa polymetallic mineral association; Melipilla polymetallic mineral association; late calcites from Melipilla low-grade disseminated mineral association; calcite from limestone host rock in Melipilla polymetallic association. The dotted colored lines mark in (a) the correlation line between Fe and $\mathrm{Mn}\left(\mathrm{r}^{2}=0.62\right.$ for Quebrada Marquesa and $\mathrm{r}^{2}=0.22$ for Melipilla polymetallic association) and $\mathrm{Mg}$ and Fe+Mn $\left(\mathrm{r}^{2}=0.58\right.$ for Quebrada Marquesa and $\mathrm{r}^{2}=0.62$ for Melipilla polymetallic association) in the propylitic hydrothermal alteration calcites. (c,d) Stratabound Mn deposits (La Serena, central Chile) and Ag-Ba veins (relatively base-metal rich and relatively base-metal poor). The dotted colred line marks in (a) the correlation line between Fe and $\mathrm{Mn}\left(\mathrm{r}^{2}=0.27\right)$ in calcite from Ag-Ba, relatively base-metal rich, veins. (e,f) Very low-grade metamorphism in volcanic rocks from La Serena and Melipilla areas (central Chile). 


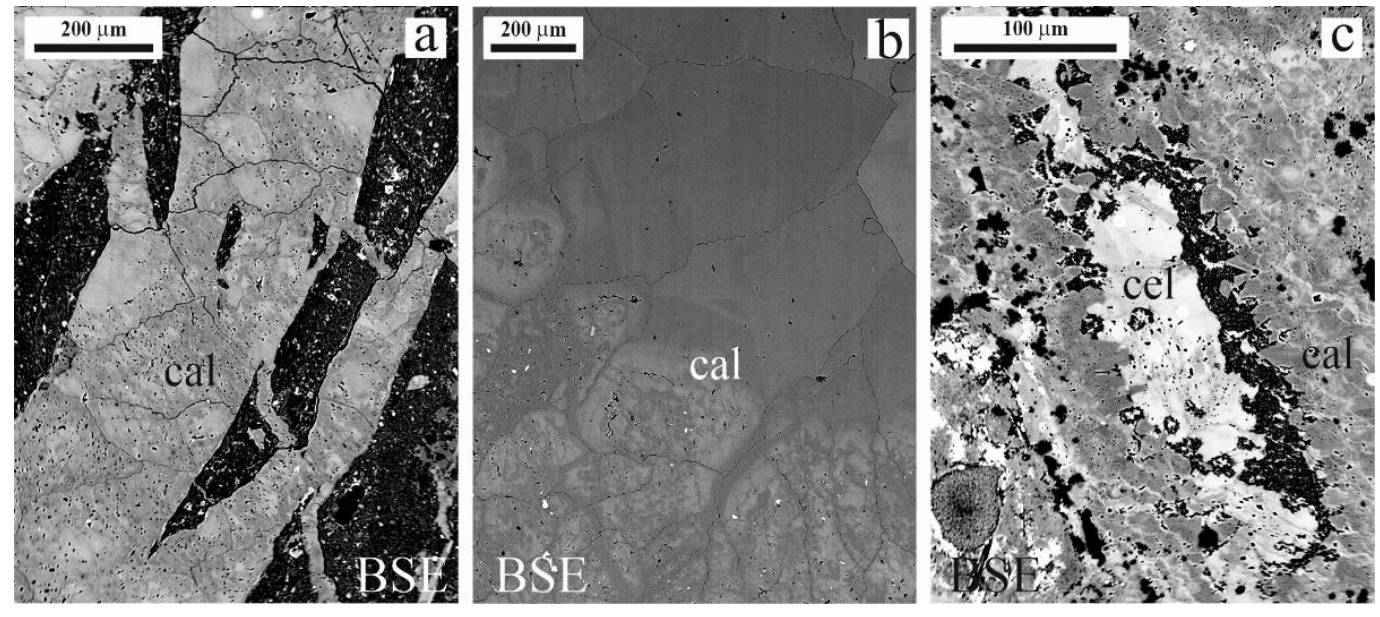

Figure 9. Back-scattered electron (BSE) images of zoned calcite aggregates crystals from "Chilean Manto-type" Cu(-Ag) deposits: (a,b) Quebrada Marquesa-La Serena- and (c) Melipilla (central Chile).
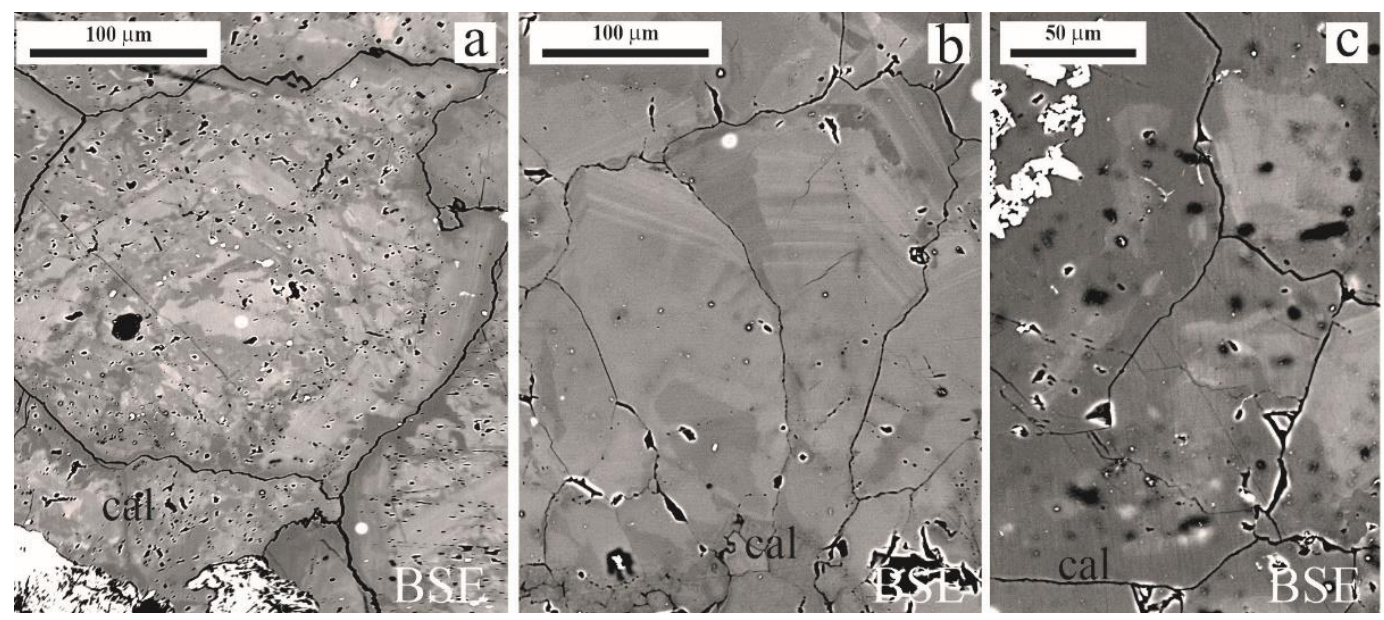

Figure 10. Back-scattered electron (BSE) images of zoned calcite aggregates crystals from: (a,b) Ag-Ba veins and (c) stratabound Mn deposits (La Serena, central Chile).

\section{Discussion}

Fluid inclusion, field-based $[23,27,28]$, and petrographic observations from the PalaiIslica deposit show that dolomite/ankerite originated through hydrothermal activity, both in the orebody and the associated zones of hydrothermal alteration. Siderite, although less common, shares the same origin but is restricted to the shallow parts of the deposit. It probably crystallized at lower $\mathrm{pH}$ due to a magmatic $\mathrm{SO}_{2}$ input into the ore fluids producing disproportionation $[27,28]$, mixed with oxidizing surface fluids (seawater and meteoric waters in an indeterminate proportion).

In contrast, the calcite observed originated by a non-mineralization-related hydrothermal process, involving circulation of seawater and eventually later meteoric phreatic waters along fractures, producing barren calcite-dolomite veins and calcite replacement of magmatic phenocrysts of the volcanic rocks. This is a regional process, which probably was triggered by the tectonic activity associated with the Carboneras strike-slip fault [40], where evidence of low-temperature fluid flow has been documented [41]. This fluid migration began, at least in the Palai-Islica area, before mineralization ( 10-9 Ma, [28]), and just after the formation of volcanic host rocks to the Au-Cu mineralization (10.4 Ma, [42]).

The formation of either dolomite or calcite, in addition to fluid chemistry, is most likely related to the precipitation temperature, as higher-temperature fluids tend to precipitate 
dolomite, whereas lower-temperature fluids typically form calcite [43] (Figure 11). The $\mathrm{Mg}$ content could be derived from the leaching of volcanic rocks. Therefore, the carbonate mineralogy in this volcanic environment reflects the contrasting environments of deposition with the presence of dolomite ( \pm siderite) related to the presence of mineralized orebodies.

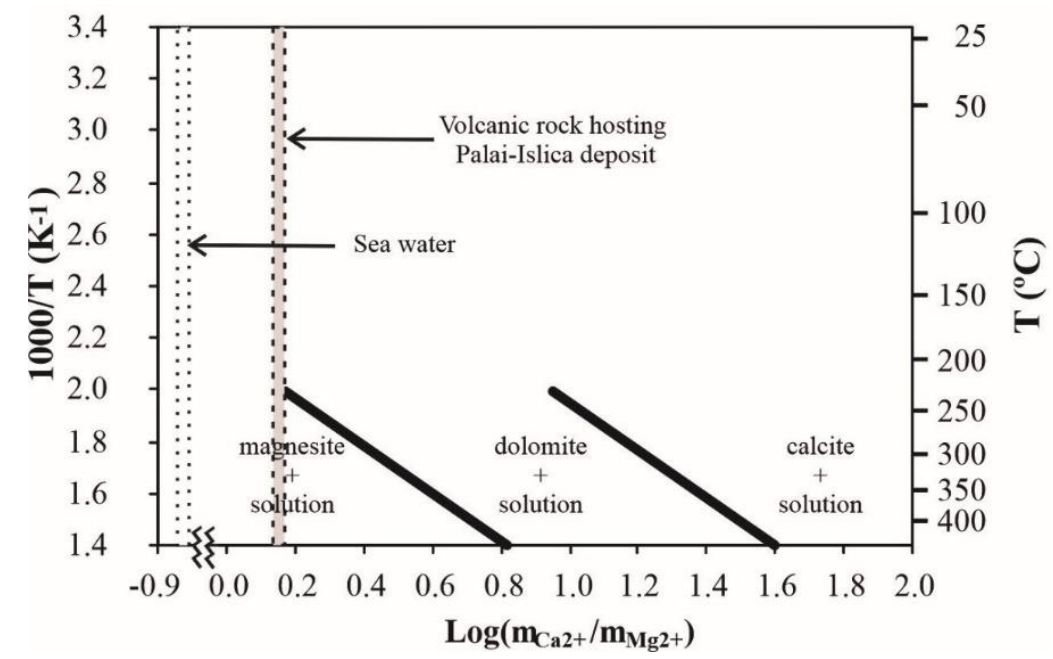

Figure 11. Binary diagram showing the stability fields of calcite, dolomite, and magnesite as the $\mathrm{Ca} / \mathrm{Mg}$ activity ratio and temperature function. The stability limits were calculated from replacing conditions of one phase by others (adapted from [43]). For reference, marine water [44] and the $\mathrm{Ca} / \mathrm{Mg}$ ratio of unaltered andesites/dacites hosting Palai-Islica deposit [45] are also shown.

The mineral composition of the carbonates in the Palai-Islica deposit, with dolomite/ ankerite generally Mn- and Fe-rich (Figure 4), offers insights into the mineralization processes. Dolomite/ankerite from the orebody tends to be more heterogeneous in composition, with higher contents of $\mathrm{Mn}$ and Fe than dolomite from the associated zones of hydrothermal alteration. Both $\mathrm{Mn}$ and Fe show subtle variations and also a significant increase in the outer zone of dolomite/ankerite crystals (zone 2 in Figure 6). This probably reflects the chemical complexity of the hydrothermal fluids [23,24,26-28], and an increase in the $\mathrm{Mn}$ and $\mathrm{Fe}$ content of the hydrothermal fluids may be associated with a recharge of deep hydrothermal metal-bearing fluids, which is coherent with the geochemical and isotopic evidence $[23,28]$.

The elevated but more restricted Mn content of the hydrothermal alteration may reflect the buffering capacity of the host volcanic rocks (typically $0.12 \mathrm{MnO} w t . \%$ [45]). In contrast, dolomite from barren veins shows lower Mn and Fe contents, which confirms the notion that elevated $\mathrm{Mn}$ and Fe concentrations correlated with the mineralizing process. As it is suggested above, these barren veins could originat from the circulation of surface waters.

The composition of calcite also correlates with the geological setting and mineral paragenesis. Calcite replacing phenocrysts, and in barren veins, and dolomite within the volcanic rocks of the Cabo de Gata volcanic belt are both Mn-poor; however, calcite from the propylitic alteration around the Palai-Islica deposit is relatively Mn-rich (and also Fe-rich). In addition, $\mathrm{Fe}$ is relatively higher in calcite replacing volcanic phenocrysts, suggesting that this is an inherited feature of the mafic phenocrysts with a high Fe content [40]. Local redox processes [46], perhaps reflecting a reducing process of the surface waters by reaction with the andesite/dacite host rocks, could also be relevant. The Mg content of calcite from the barren veins is typically elevated, possibly due to a relatively higher temperature of formation of these veins according to the calcite-dolomite geothermometer when calcite and dolomite coexist [47]. Therefore, in the Palai-Islica area, the Mn (and in some cases, Fe) content of carbonates is an excellent indicator of a hydrothermal, and potentially ore-related, origin. 
At the El Dorado epithermal $\mathrm{Cu}$-Au deposit, ankerite is typically found within veins with sulfides. The ankerite is Mn- and Fe-rich, with Fe contents much higher than in ankerite from Palai-Islica. At El Dorado, the zonation of ankerite crystals (Figure 7) suggests that the chemical evolution of the carbonate, evidenced by contrasting chemical zones, is the opposite to that at Palai-Islica, with a slight decrease of the Mn and Fe content in ankerite crystals with time. This chemical evolution was perhaps due to the progressive input of oxidizing meteoric fluids, in the latest stage of the hydrothermal-magmatic system that produced the ore mineralization.

The presence or absence of dolomite/ankerite and calcite at the Palai-Islica or El Dorado deposits is linked to the style of mineralization. Both deposits are considered intermediate/(high)-sulfidation epithermal deposits [27-29], which, by definition, usually lack carbonates as a significant gangue phase. They contrast with low-sulfidation epithermal deposits, which commonly have calcite as a gangue phase (e.g., [48,49]). The timing of dolomite precipitation, late in the paragenetic evolution of the Palai-Islica and El Dorado intermediate(/high)-sulfidation epithermal deposits, is consistent with the $\mathrm{pH}$ of the ore fluids having been neutralized by their interaction with the host rocks and the acquisition of sufficient $\mathrm{Mg}$ to form dolomite rather than calcite.

The "Chilean Manto-type" Cu(-Ag), Ag-Ba veins, and stratabound Mn deposits investigated from central Chile have calcite \pm barite as major gangue minerals and are hosted within volcanic rocks, typically of andesitic composition, and sedimentary rocks. The existence of calcite rather than dolomite suggests that the activity of $\mathrm{Mg}^{2+}$ in the ore-forming fluids was relatively low, because even at low $\mathrm{Mg} / \mathrm{Ca}$ values at the typical range of epithermal temperatures (i.e., $150-250{ }^{\circ} \mathrm{C}$ ), dolomite should precipitate rather than calcite [43] (Figure 11).

In the polymetallic association of "Chilean Manto-type" $\mathrm{Cu}(-\mathrm{Ag})$ deposits, the calcite is Mn-rich and, to a lesser extent, Fe-rich (Figure 8a,b). Calcite in Ag-Ba veins is less Fe-rich and less Mn-rich than calcite from "Chilean Manto-type" $\mathrm{Cu}(-\mathrm{Ag}$ ) deposits (Figure 8), which also correlates with the lower sulfur and metal content of these veins. Consideration of the calcite data exclusively from Ag-Ba veins shows that veins with higher metal contents give higher $\mathrm{Mn}$ and Fe contents than calcite from Ag-Ba veins with lower total metal contents (Figure $8 \mathrm{c}, \mathrm{d}$ ). Finally, calcite from very low-grade metamorphic rocks hosting the stratabound deposits are always Mn-poor, and in the case of La Serena, also Fe and Mgpoor (Figure 8e,f). Therefore, these deposits invariably preserve the correlation between the Mn content of calcite and associated mineralization, which reflects the Mn content of the hydrothermal fluids, and metal content (mainly $\mathrm{Cu}$ ) of hydrothermal fluids.

It is also noteworthy that carbonates in the stratabound Mn deposits are Mn (and $\mathrm{Fe}$ )-poor. The explanation for the low Mn content could be because the hydrothermal fluids that precipitated the low $\mathrm{Mn}$ calcite and barite were not related directly to Mn-ore precipitation but precipitated in a later stage, being dominated by oxidizing meteoric waters with a low Mn content. Petrographically, the calcite in this deposit is clearly associated with $\mathrm{Mn}$ ore minerals, although it is observed that calcite postdates $\mathrm{Mn}$ minerals in the mineral paragenesis. In either case, further fluid inclusion and isotopic studies performed in this calcite could decipher fluids related to late-stage ore formation or recrystallization of $\mathrm{Mn}$-ores instead of the conditions extant during the formation of primary Mn ores. An equivalent argument could be made for calcite from Melipilla low-grade disseminated mineral association, also witha very low $\mathrm{Mn}$ (and Fe) content (Figure 8a,b) and paragenitically late.

These new data on the mineral compositions of carbonates clearly support the idea previously described that $\mathrm{Mn}$ can be used a as whole-rock element index of hydrothermalore bearing activity (e.g., $[18,19])$ and previous studies that showed elevated concentrations of $\mathrm{Mn}$ (and $\mathrm{Fe}$ ) in carbonates related to precious and base-metal hydrothermal deposits (e.g., [6,15-17]). In contrast, where the carbonates are paragenetically late or unrelated to the mineralization, they show markedly lower Mn contents (0.00-0.08 at. \%, in contrast with associated ore mineralization, with up to 1.63 at. \%). This Mn depletion was also noted in the hydrothermal Irish $\mathrm{Zn}-\mathrm{Pb}$ ore-field [6]. Moreover, these observations are consistent 
with measurements of the Mn content of different types of hydrothermal fluids (Table 2). Although there are several factors that control Mn incorporation into calcite (kinetics of precipitation; composition of the fluid, particularly the $\mathrm{Mn} / \mathrm{Ca}$ ratio; precipitation of other minerals (e.g., $[46,50,51]))$, simple calculations with distribution coefficients estimated for temperatures ranging between 150 and $250{ }^{\circ} \mathrm{C}$, constrained by fluid-inclusion data in the studied carbonates (references in Table 1), suggest the potential of ore-forming fluids to produce Mn-rich calcite (Table 2).

Table 2. Range of concentrations of Mn and Ca found in different types of fluids.

\begin{tabular}{|c|c|c|c|c|c|}
\hline & \multirow{2}{*}{$\underset{(\mu \mathrm{Mol} / \mathrm{kg})}{\operatorname{Mn}}$} & \multirow{2}{*}{$\begin{array}{c}\mathrm{Ca} \\
(\mu \mathrm{Mol} / \mathrm{kg})\end{array}$} & \multicolumn{3}{|c|}{ Mn at. \% (Calcite) } \\
\hline & & & $150{ }^{\circ} \mathrm{C}$ & $200{ }^{\circ} \mathrm{C}$ & $250{ }^{\circ} \mathrm{C}$ \\
\hline \multirow{2}{*}{ Hydrothermal sea vents ${ }^{(1)}$} & 15 & 22,000 & 0.11 & 0.07 & 0.04 \\
\hline & 6800 & 80,000 & 14.03 & 8.93 & 5.53 \\
\hline \multirow{2}{*}{ Geothermal fluids $(2,3)$} & 0 & 7 & 0.42 & 0.27 & 0.17 \\
\hline & 146 & 699 & 25.00 & 21.89 & 13.55 \\
\hline \multirow{2}{*}{ Metamorphic fluids (2) } & 0 & 136 & 0.00 & 0.00 & 0.00 \\
\hline & 5 & 475 & 1.74 & 1.10 & 0.68 \\
\hline Sea water ${ }^{(1)}$ & 0 & 10,200 & 0.00 & 0.00 & 0.00 \\
\hline
\end{tabular}

Note: Data from compilations of 1: [52]; 2: [53]; 3: [54]. Estimations of Mn concentration (in atomic \%) in calcite precipitating from these fluids assuming distribution coefficients [46] at temperatures from 150 to $250{ }^{\circ} \mathrm{C}$, and the extreme Mn and Ca values for these different types of fluids.

Furthermore, with the measured Mn calcite content, and assuming different Ca concentrations of the fluids (fluid-inclusion data suggest a relatively high Ca content in Chilean samples [32]), the Mn content of the hydrothermal and metamorphic fluids was estimated. These Mn values, according to the performed calculations, could be considerably higher than $100 \mu \mathrm{Mol} / \mathrm{kg}$ for the "Chilean Manto-type" $\mathrm{Cu}(-\mathrm{Ag})$, and Ag-Ba veins, whereas for the very low-grade metamorphism and calcite from the Mn stratabound deposit it could be two orders of magnitude lower (Table 3).

The chemical zonation in carbonate minerals from "Chilean Manto-type" $\mathrm{Cu}(-\mathrm{Ag}), \mathrm{Ag}$ Ba veins, and stratabound $\mathrm{Mn}$ deposits is consistent with fluctuations in the chemistry of hydrothermal fluids (Figures 9 and 10). The textures in "Chilean Manto-type" $\mathrm{Cu}(-\mathrm{Ag}$ ), and Ag-Ba veins such as "caries" texture (Figures 9 and 10) suggest dissolution reprecipitation of calcite, which reflects changes during hydrothermal activity. In both cases, similar textures are found, a fact that could indicate that in the La Serana area "Chilean Manto-type" Cu($\mathrm{Ag}$ ), and Ag-Ba veins are deposits with a clear genetic link. Furthermore, in both cases, the late calcite is $\mathrm{Mn}$ and Fe poor. In other context, such in low low-temperature fluid systems developed in the Pyrenees during its tectonic evolution, calcite also shows a late Mn and Fe decrease. This chemical evolution has been interpreted as the system was dominated by low-temperature meteoric waters due to uplifting processes. In our case, this chemical pattern could hypothetically suggest an input of meteoric waters due to the exhumation and uplift of the region during late Cretaceous associated with Peruvian orogeny, and after the region had experienced a very low-grade metamorphism [37-39,55,56]. 
Table 3. Estimates of the Mn content of hydrothermal/metamorphic fluids from the studied areas according to the concentration of $\mathrm{Mn}$ in calcites precipitated (minimum, maximum, and average Mn content), the distribution coefficient of [46], and different possible values of Ca in the hydrothermal fluids.

\begin{tabular}{|c|c|c|c|c|c|c|c|c|c|c|}
\hline & \multirow{2}{*}{$\begin{array}{l}\text { Mn (at. \%) } \\
\text { Calcite }\end{array}$} & \multicolumn{3}{|c|}{$\mathrm{Mn}(\mu \mathrm{Mol} / \mathrm{kg}) 150^{\circ} \mathrm{C}$} & \multicolumn{3}{|c|}{$\mathrm{Mn}(\mu \mathrm{Mol} / \mathrm{kg}) 200^{\circ} \mathrm{C}$} & \multicolumn{3}{|c|}{$\mathrm{Mn}(\mathrm{uMol} / \mathrm{kg}) 250^{\circ} \mathrm{C}$} \\
\hline & & $\mathbf{A}$ & B & $\mathrm{C}$ & $\mathbf{A}$ & B & $\mathrm{C}$ & A & B & $\mathrm{C}$ \\
\hline \multirow{3}{*}{$\begin{array}{l}\text { Quebrada Marquesa } \\
\text { ("Manto-type" Cu(-Ag)) }\end{array}$} & 0.01 & 0 & 2 & 4 & 1 & 3 & 7 & 1 & 5 & 11 \\
\hline & 1.63 & 101 & 504 & 1008 & 158 & 792 & 1584 & 256 & 1280 & 2559 \\
\hline & 0.51 & 31 & 156 & 313 & 49 & 246 & 491 & 79 & 397 & 793 \\
\hline \multirow{3}{*}{$\begin{array}{c}\text { Melipilla } \\
\text { ("Manto-type" Cu(-Ag)) }\end{array}$} & 0.28 & 17 & 86 & 172 & 27 & 136 & 271 & 44 & 219 & 438 \\
\hline & 1.92 & 119 & 593 & 1186 & 186 & 932 & 1863 & 301 & 1505 & 3010 \\
\hline & 0.65 & 40 & 200 & 400 & 63 & 314 & 628 & 101 & 507 & 1015 \\
\hline \multirow{3}{*}{$\begin{array}{c}\text { Quebrada Marquesa } \\
\text { (Ag-Ba veins) }\end{array}$} & 0.03 & 2 & 10 & 20 & 3 & 16 & 31 & 5 & 25 & 50 \\
\hline & 0.94 & 58 & 291 & 583 & 92 & 458 & 916 & 148 & 740 & 1480 \\
\hline & 0.37 & 23 & 115 & 230 & 36 & 180 & 361 & 58 & 291 & 583 \\
\hline \multirow{3}{*}{$\begin{array}{c}\text { Arqueros } \\
\text { (stratabound Mn) }\end{array}$} & 0.00 & 0 & 0 & 0 & 0 & 0 & 0 & 0 & 0 & 0 \\
\hline & 0.32 & 20 & 100 & 200 & 31 & 157 & 315 & 51 & 254 & 508 \\
\hline & 0.04 & 3 & 13 & 26 & 4 & 21 & 42 & 7 & 34 & 67 \\
\hline \multirow{3}{*}{$\begin{array}{l}\text { Very low-grade } \\
\text { metamorphism }\end{array}$} & 0.00 & 0 & 0 & 0 & 0 & 0 & 0 & 0 & 0 & 0 \\
\hline & 0.08 & 5 & 26 & 52 & 8 & 41 & 82 & 13 & 66 & 132 \\
\hline & 0.02 & 1 & 6 & 11 & 2 & 9 & 17 & 3 & 14 & 28 \\
\hline
\end{tabular}

Note: Calculated with a concentration of Ca of equivalent $x$ times sea water Ca content: (A) 1 ; (B) 5 ; (C) 10.

\section{Conclusions}

Carbonate mineralogy and composition was demonstrated as a useful method to distinguish between ore-related hydrothermal alteration and regional alteration. Thus, in Palai-Islica volcanic hosted epithermal deposit, calcite( \pm dolomite) is associated with regional alteration. Meanwhile, dolomite $( \pm$ ankerite \pm siderite) is associated with the hydrothermal ore system. On the other hand, carbonates directly related to ore-forming processes and base-metal precipitation tend to show elevated Mn (and, to a lesser extent, $\mathrm{Fe}$ ) contents. Thus, dolomite from the Palai-Islica deposit and local area shows this distinctive Mn average content: orebody veins (0.60 at. \%) > hydrothermal alteration $(0.44$ at. $\%)$ $>$ barren veins ( 0.16 at. \%). Additionally, calcite from the La Serena area also shows an average $\mathrm{Mn}$ content clearly associated with its origin: "Chilean Manto-type" $\mathrm{Cu}(-\mathrm{Ag})$ $(0.51$ at. \%) > metal rich Ag-Ba veins, $(0.44$ at. \%) > metal poor Ag-Ba veins (0.12 at. \%) $>$ barren samples associated with very low-grade metamorphism (0.01 at. \%). Instead, the $\mathrm{Mg}$ concentration in calcite is not directly correlated with ore-forming hydrothermal fluids but, maybe, with high-temperature, non-metal-rich fluids.

Carbonates from the mineralization typically show chemical zonation, although a unique pattern was not observed. In the two studied epithermal volcanic hosted deposits, subtle oscillatory patterns and more contrasting chemical zones were distinguished in dolomite/ankerite, reflecting a complex chemical evolution of the hydrothermal system. In "Chilean Manto-type" and Ag-Ba veins, dissolution textures in calcite are common, reflecting a late $\mathrm{Mn}(-\mathrm{Fe})$ stage, which could correspond with a stage dominated by oxidizing meteoric fluids. This similar zonation pattern among these two kinds of deposit also suggests a genetic link between both types of deposits.

The textural (space infillings) and chemical characterization (Mn, and very low $\mathrm{Fe}$ content) of the studied samples also showed two cases where calcite (stratabound Mn deposits of Quebrada Marquesa; low-grade disseminated mineral association from a "Chilean Manto-type" mineralization in Melipilla) is probably not related to the ore mineralization processes, perhaps reflecting the circulation of later meteoric waters post-mineralization. This conclusion should prevent us from using stable and radiogenic isotope analyses of these carbonates in the modeling of the primary genesis of these deposits. 
In summary, the textures and chemical composition of carbonates provide an interesting and effective tool to fully constrain the likely origin of the carbonate phases and may help to discern or dismiss links between different styles of mineralization within a given area. It may be particularly useful prior to the application of stable and radiogenic isotope analyses of carbonate phases or simply as another tool in mineral exploration.

Supplementary Materials: The following are available online at https:/ /www.mdpi.com/article/10 $.3390 / \mathrm{min} 11080822 / \mathrm{s} 1$, Table S1: Summary of EPMA analysis of carbonates from epithermal $\mathrm{Au}-\mathrm{Cu}$ deposits (Palai-Islica-SE Spain, and El Dorado-Central Chile) and host rock. Table S2: Summary of EPMA analysis of calcites from "Chilean Manto-type" $\mathrm{Cu}(-\mathrm{Ag})$ deposits (La Serena-Quebrada Marquesa- and Melipilla, Central Chile). Table S3: Summary of EPMA analysis of calcites from stratabound Mn and Ag-Ba vein deposits (Quebrada Marquesa and Arqueros -La Serena-, central Chile). Table S4: Summary of EPMA analysis of calcites from very low-grade metamorphism (La Serena and Melipilla, central Chile).

Author Contributions: Conceptualization, J.C.-R., S.M.-R. and D.M.; methodology, J.C.-R., S.M.-R. and M.B.; sampling and data collection, J.C.-R., S.M.-R., D.M. and M.B.; data analysis, J.C.-R., S.M.-R. and D.M.; interpretation data and discussion: J.C.-R., S.M.-R., D.M. and S.R.; writing-original draft preparation, J.C.-R., S.M.-R., D.M. and S.R.; writing-review and editing, J.C.-R., S.M.-R., S.R., D.M. and M.B., funding acquisition, J.C.-R. and S.M.-R. All authors have read and agreed to the published version of the manuscript.

Funding: The research was initially supported by the Spanish projects BTE-2003-06265 and CGL200602594-BTE (Ministry of Science and Technology/Ministry of Science and Innovation/Ministry of Education and Science and FEDER), the RNM 131 of Junta de Andalucía, and the Chilean FONDECYT Project 1031000.

Institutional Review Board Statement: Not applicable.

Data Availability Statement: Not applicable.

Acknowledgments: We thank Fernando de la Fuente, Tsuyoshi Nishimura, Roberto Belmar, Alonso Toledo and Olga Veloso for their collaboration on this research and for their help to access to the studied mines and samples. The manuscript was significantly improved by the helpful suggestions and critiques of two anonymous reviewers. Assistant editor, Vivi Li, are also thanked for her help and encouragement.

Conflicts of Interest: The authors declare no conflict of interest.

\section{References}

1. Polgari, M.; Okita, P.M.; Hein, J.R. Stable isotope evidence for the origin of the Úrkút manganese ore deposit, Hungary. J. Sediment. Res. 1991, 61, 384-393. [CrossRef]

2. Spangenberg, J.; Fontbote, L.; Sharp, Z.D.; Hunziker, J. Carbon and oxygen isotope study of hydrothermal carbonates in the zinc-lead deposits of the San Vicente district, central Peru: A quantitative modeling on mixing processes and $\mathrm{CO}_{2}$ degassing. Chem. Geol. 1996, 133, 289-315. [CrossRef]

3. Bouzenoune, A.; Lecolle, P. Petrographic and geochemical arguments for hydrothermal formation of the Ouenza siderite deposit (NE Algeria). Mineral. Depos. 1997, 32, 189-196. [CrossRef]

4. Gianelli, G.; Ruggieri, G.; Mussi, M. Isotopic and fluid-inclusion study of hydrothermal and metamorphic carbonates in the Larderello geothermal field and surrounding areas, Italy. Geothermics 1997, 26, 393-417. [CrossRef]

5. Castorina, F.; Masi, U. Sr-isotopic composition of siderite for assessing the origin of mineralizing fluid: The case study from the Jebel Awam deposit (Central Morocco). Ore Geol. Rev. 2000, 17, 83-89. [CrossRef]

6. Wilkinson, J.J.; Earls, G. A high-temperature hydrothermal origin for black dolomite matrix breccias in the Irish $\mathrm{Zn}-\mathrm{Pb}$ orefield. Mineral. Mag. 2000, 64, 1017-1036. [CrossRef]

7. Lavric, J.; Spangenberg, J. Stable isotope (C, O, S) systematics of the mercury mineralization at Idrija, Slovenia: Constraints on fluid source and alteration processes. Mineral. Depos. 2003, 38, 886-899. [CrossRef]

8. Wilkinson, J.J.; Everett, C.E.; Boyce, A.J.; Gleeson, S.A.; Rye, D.M. Intracratonic crustal seawater circulation and the genesis of subseafloor zinc-lead mineralization in the Irish orefield. Geology 2005, 33, 805-808. [CrossRef]

9. Schroll, E.; Koppel, V.; Cerny, I. Pb and Sr isotope and geochemical data from the Pb-Zn deposit Bleiberg (Austria): Constraints on the age of mineralization. Mineral. Petrol. 2006, 86, 129-156. [CrossRef]

10. Song, Y.; Hou, Z.; Cheng, Y.; Yang, T.; Xue, C. Fluid inclusion and isotopic constraints on the origin of ore-forming fluid of the Jinman-Liancheng vein $\mathrm{Cu}$ deposit in the Lanping Basin, western Yunnan, China. Geofluids 2016, 16, 56-77. [CrossRef] 
11. Marques de Sá, C.; Noronha, F.; Cardellach, E.; Bobos, I. Fluid inclusion and (S, C, O, Pb) isotope study of Pb-Zn-(Cu-Ag) hydrothermal veins from Central and Northern Portugal-Metallogenic implications. Ore Geol. Rev. 2019, 112, 1-15. [CrossRef]

12. Moroni, M.; Rossetti, P.; Naitza, S.; Magnani, L.; Ruggieri, G.; Aquino, A.; Tartarotti, P.; Franklin, A.; Ferrari, E.; Castelli, D.; et al. Factors controlling hydrothermal nickel and cobalt mineralization-Some suggestions from historical ore deposits in Italy. Minerals 2019, 9, 429. [CrossRef]

13. Maghfouri, S.; Hosseinzadeh, M.R.; Lentz, D.R.; Tajeddin, H.A.; Movahednia, M.; Shariefi, A. Nature of ore-forming fluids in the Mehdiabad world-class sub-seafloor replacement SEDEX-type $\mathrm{Zn}-\mathrm{Pb}$-Ba-(Cu-Ag) deposit, Iran; constraints from geochemistry, fluid inclusions, and O-C-Sr isotopes. J. Asian Earth Sci. 2021, 207, 104654. [CrossRef]

14. Frondel, C. The Minerals of Franklin and Sterling Hill, a Checklist; John Wiley \& Sons: New York, NY, USA, 1972; 94p.

15. Jebrak, M. Le district filonien a Pb-Zn-Ag et carbonates du Jebel Aouam (Maroc central). Bull. Mineral. 1985, 108, 487-498. [CrossRef]

16. Polgari, M.; Forizs, I. Distribution of Mn in carbonates from the Upony Mts., NE-Hungary. Geol. Carpathica 1996, 47, $215-225$.

17. Akçay, M.; Özkan, H.M.; Spiro, B.; Wilson, R.; Hoskin, P.W.O. Geochemistry of a high-T hydrothermal dolostone from the Emirli (Ödemis, western Turkey) Sb-Au deposit. Mineral. Mag. 2003, 67, 671-688. [CrossRef]

18. Russell, M.J. Manganese halo surrounding the Tynagh ore deposit, Ireland: A preliminary note. Trans. Inst. Min. Metall. 1974, 83, B65-B66.

19. Gwosdz, W.; Krebs, W. Manganese halo surrounding Meggan ore deposit, Germany. Trans. Inst. Min. Metall. 1977, 86, B73-B77.

20. Cruset, D.; Cantarero, I.; Vergés, J.; John, C.M.; Muñoz-López, D.; Travé, A. Changes in fluid regime in syn-orogenic sediments during the growth of the south Pyrenean fold and thrust belt. Glob. Planet. Chang. 2018, 171, 207-224. [CrossRef]

21. Motte, G.; Hoareau, G.; Callot, J.-P.; Révillon, S.; Piccoli, F.; Calassou, S.; Gaucher, E.C. Rift and salt-related multi-phase dolomitization: Example from the northwestern Pyrenees. Mar. Pet. Geol. 2021, 126, 104932. [CrossRef]

22. Cruset, D.; Ibáñez-Insa, J.; Cantarero, I.; John, C.M.; Travé, A. Significance of fracture-filling rose-like calcite crystal clusters in the SE pyrenees. Minerals 2020, 10, 522. [CrossRef]

23. Morales Ruano, S.; Carrillo Rosúa, F.J.; Fenoll Hach-Alí, P.; de la Fuente Chacón, F.; Contreras López, E. Epithermal Cu-Au mineralization in the Palai-Islica deposit, Almería, southeastern Spain: Fluid inclusion evidence of mixing of fluids as guide to gold mineralization. Can. Mineral. 2000, 38, 553-566. [CrossRef]

24. Carrillo-Rosúa, F.J.; Morales-Ruano, S.; Fenoll Hach-Ali, P. Iron sulphides at the epithermal gold-copper deposit of Palai-Islica (Almeriía, SE Spain). Mineral. Mag. 2003, 67, 1059-1080. [CrossRef]

25. Carrillo-Rosúa, F.J.; Morales Ruano, S.; Morata Céspedes, D. Mineral features of Cu-Ag-Ba-Mn mineralisations of La Serena, Chile. In Mineral Exploration and Sustainable Development; Eliopoulos, D.G., Eilu, P., Economou-Eliopoulos, M., Damigos, D., Christidis, G., Brown, A., Bouchot, V., Borg, G., Boni, M., Benardos, A., et al., Eds.; Millpress: Rotterdam, The Netherlands, 2003; Volume 2, pp. 953-956.

26. Carrillo-Rosúa, J.; Morales-Ruano, S.; Fenoll Hach-Alí, P. Textural and chemical features of sphalerite from the Palai-Islica deposit (SE Spain): Implications for ore genesis and color. Neues Jahrb. Mineral. Abh. 2008, 185, 63-78. [CrossRef]

27. Carrillo-Rosúa, J.; Morales-Ruano, S.; Esteban-Arispe, I.; Fenoll Hach-Alí, P. Significance of phyllosilicate mineralogy and mineral chemistry in an epithermal environment. Insights from the Palai-Islica Au-Cu deposit (Almería, SE Spain). Clays Clay Miner. 2009, 57, 1-24. [CrossRef]

28. Carrillo-Rosúa, J. El Depósito Epitermal de Oro-Cobre Palai-Islica (Carboneras, Almería). Mineralogía, Geoquímica y Metalogenia. Unpublished Ph.D. Thesis, Universidad de Granada, Granada, Spain, 2005; 421p.

29. Carrillo-Rosúa, J.; Morales-Ruano, S.; Morata, D.; Boyce, A.J.; Belmar, M.; Fallick, A.E.; Fenoll Hach-Alí, P. Mineralogy and geochemistry of El Dorado epithermal gold deposit, El Sauce district, central-northern Chile. Mineral. Petrol. 2008, 92, 341-360. [CrossRef]

30. Boric, R. Geología y yacimientos metálicos del Distrito Talcuna, Región de Coquimbo. Andean Geol. 1985, 25-26, 57-75.

31. Oyarzun, R.; Ortega, L.; Sierra, J.; Lunar, R.; Oyarzun, J. Cu, Mn and Ag mineralization in the Quebrada Marquesa Quadrangle: The Talcuna and Arqueros district. Mineral. Depos. 1998, 33, 547-559. [CrossRef]

32. Carrillo-Rosúa, F.J.; Morales Ruano, S.; Morata, D.; Belmar, M.; Fenoll Hach-Alí, P. Fluidos relacionados con diferentes mineralizaciones de $\mathrm{Cu}-\mathrm{Ag}$ y metamorfismo de bajo grado en el área de la Serena (Cordillera de la Costa, Chile Central). Datos preliminares. Macla 2004, 2, 89-90.

33. Carrillo-Rosúa, J.; Boyce, A.J.; Morales-Ruano, S.; Morata, D.; Roberts, S.; Munizaga, F.; Moreno-Rodríguez, V. Extremely negative and inhomogeneous sulfur isotope signatures in Cretaceous Chilean manto-type $\mathrm{Cu}-(\mathrm{Ag})$ deposits, Coastal Range of central Chile. Ore Geol. Rev. 2014, 56, 13-24. [CrossRef]

34. Turner, S.P.; Platt, J.P.; George, R.M.M.; Kelley, S.P.; Pearson, D.G.; Nowell, G.M. Magmatism associated with orogenic collapse of the Betic-Alboran domain, SE Spain. J. Petrol. 1999, 40, 1011-1036. [CrossRef]

35. Carrillo-Rosúa, F.J.; Morales Ruano, S.; Fenoll Hach-Alí, P. The three generations of gold in the Palai-Islica epithermal deposit, southeastern Spain. Can. Mineral. 2002, 40, 1465-1481. [CrossRef]

36. Aguirre, L.; Egert, E. Cuadrángulo Quebrada Marquesa, provincia de Coquimbo. Carta Geol. de Chile Inst. de Investig. Geol. 1965, 15, 92.

37. Morata, D.; Féraud, G.; Aguirre, L.; Arancibia, G.; Belmar, M.; Morales, S.; Carrillo, J. Geochronology of the lower cretaceous volcanism from the Coastal Range $\left(29^{\circ} 20^{\prime}-30^{\circ} \mathrm{S}\right)$, Chile. Rev. Geol. Chile 2008, 35, 123-145. [CrossRef] 
38. Morata, D.; Aguirre, L. Extensional Lower Cretaceous volcanism in the Costal Range $\left(29^{\circ} 20^{\prime}-30^{\circ} 00^{\prime} \mathrm{S}\right)$ Chile: Geochemistry and petrogenesis. J. S. Am. Earth Sci. 2003, 16, 459-476. [CrossRef]

39. Morata, D.; Aguirre, L.; Belmar, M.; Morales, S. Constraining very low-grade metamorphic conditions based on prehnite chemistry. In Proceedings of the Congreso Geológico Chileno, Concepción, Chile, 6-10 October 2003.

40. Rutter, E.H.; Faulkner, D.R.; Burgess, R. Structure and geological history of the Carboneras Fault Zone, SE Spain: Part of a stretching transform fault system. J. Struct. Geol. 2012, 45, 68-71. [CrossRef]

41. Abad, I.; Jiménez-Millán, J.; Schleicher, A.M.; van der Pluijm, B.A. Mineral characterization, clay quantification and Ar-Ar dating of faulted schists in the Carboneras and Palomares Faults (Betic Cordillera, SE Spain). Eur. J. Mineral. 2017, 29, 17-34. [CrossRef]

42. Bellon, H.; Bordet, P.; Montenat, C. Chronologie du magmatisme Néogène des Cordillères Bètiques (Espagne mèridionale). Bull. Soc. Geol. France 1983, 25, 205-217. [CrossRef]

43. Rosenberg, P.E.; Holland, H.D. Calcite-dolomite magnesite stability relations in solutions at elevated temperatures. Science 1964, 145, 700-701. [CrossRef]

44. Garrels, R.M.; Thompson, M.E. A chemical model for sea water at $25^{\circ} \mathrm{C}$ and one atm. total pressure. Am. J. Sci. 1962, $260,57-66$. [CrossRef]

45. Fernández Soler, J.M. El Vulcanismo Calco-Alcalino en el Parque Natural de Cabo de Gata-Nijar (Almería). Estudio Volcanológico y Petrológico. Ph.D. Thesis, University of Granada, Granada, Spain, 1996; 295p.

46. Rimstidt, J.D.; Balog, A.; Webb, J. Distribution of carbonate minerals and aqueous solutions. Geochim. Cosmochim. Acta 1998, 62, 1851-1863. [CrossRef]

47. Anovitz, L.M.; Essene, E.J. Phase Equilibria in the System $\mathrm{CaCO}_{3}-\mathrm{MgCO}_{3}-\mathrm{FeCO}_{3}$. J. Petrol. 1987, 28, 389-415. [CrossRef]

48. Heald, P.; Foley, N.K.; Hayba, D.O. Comparative anatomy of volcanic-hosted epithermal deposits; acid-sulfate and adulariasericite types. Econ. Geol. 1987, 82, 1-26. [CrossRef]

49. Hedenquist, J.W.; Arribas., A.; Gonzalez-Urien, E. Exploration for epithermal gold deposits. In Gold in 2000; Hagemann, S.G., Brown, P.E., Eds.; Society of Economic Geologists: Littleton, CO, USA, 2000.

50. Wang, Y.; $\mathrm{Xu}, \mathrm{H}$. Prediction of trace metal partitioning between minerals and aqueous solutions: A linear free energy correlation approach. Geochim. Cosmochim. Acta 2001, 65, 1529-1543. [CrossRef]

51. Böttcher, M.E.; Dietzel, M. Metal-ion partitioning during low-temperature precipitation and dissolution of anhydrous carbonates and sulphates. Eur. Mineral. Union Notes Mineral. 2010, 10. [CrossRef]

52. Scott, S.D. Submarine hydrothermal systems and deposits. In Geochemistry of Hydrothermal Ore Deposits, 3rd ed.; Barnes, H.L., Ed.; John Wiley \& Sons: New York, NY, USA, 1997; pp. 435-486.

53. Yardley, B.W.D. Metal concentrations in crustal fluids and their relationship to ore formation. Econ. Geol. 2005, 100, 613-632. [CrossRef]

54. McKibben, M.A.; Hardie, L.A. Ore-forming brines in active continental rifts. In Geochemistry of Hydrothermal Ore Deposits, 3rd ed.; Barnes, H.L., Ed.; John Wiley \& Sons: New York, NY, USA, 1997; pp. 877-935.

55. Charrier, R.; Ramos, V.A.; Tapia, F.; Sagripanti, L. Tectono-stratigraphic evolution of the Andean Orogen between 31 and $37^{\circ} \mathrm{S}$ (Chile and Western Argentina). Geol. Soc. Lond. Spec. Publ. 2015, 399. [CrossRef]

56. Wilson, N.S.F.; Zentilli, M.; Reynolds, P.H.; Boric, R. Age of mineralization by basinal fluids at the El Soldado manto-type copper deposit, Chile: ${ }^{40} \mathrm{Ar} /{ }^{39} \mathrm{Ar}$ geochronology of K-feldspar. Chem. Geol. 2003, 197, 161-176. [CrossRef] 